\title{
CARACTERÍSTICAS DE CARCAÇAS BOVINAS OBTIDAS POR FRIGORÍFICOS NA REGIÃO CENTRAL DO BRASIL, UM RETRATO ESPACIAL E TEMPORAL
}

\author{
RAFAEL FERREIRA SORIA
}

Dissertação apresentada à Escola Superior de Agricultura "Luiz de Queiroz", Universidade de São Paulo, para obtenção do título de Mestre em Agronomia, Área de Concentração: Ciência Animal e Pastagens.

PIRACICABA

Estado de São Paulo - Brasil

Agosto - 2005 


\title{
CARACTERÍSTICAS DE CARCAÇAS BOVINAS OBTIDAS POR FRIGORÍFICOS NA REGIÃO CENTRAL DO BRASIL, UM RETRATO ESPACIAL E TEMPORAL
}

\author{
RAFAEL FERREIRA SORIA \\ Médico Veterinário
}

Orientador: Prof. Dr. EDUARDO FRANCISQUINE DELGADO

\begin{abstract}
Dissertação apresentada à Escola Superior de Agricultura "Luiz de Queiroz", Universidade de São Paulo, para obtenção do título de Mestre em Agronomia, Área de Concentração: Ciência Animal e Pastagens.
\end{abstract}

PIRACICABA

Estado de São Paulo - Brasil

Agosto - 2005 
Dados Internacionais de Catalogação na Publicação (CIP) DIVISÃO DE BIBLIOTECA E DOCUMENTAÇÃO - ESALQ/USP

Soria, Rafael Ferreira

Características de carcaças bovinas obtidas por frigoríficos na região central do Brasil: um retrato espacial e temporal / Rafael Ferreira Soria. - - Piracicaba, 2005.

60 p. : il.

Dissertação (Mestrado) - - Escola Superior de Agricultura Luiz de Queiroz, 2005.

Bibliografia.

1. Bovinos de corte 2. Carcaça - Qualidade 3. Carne bovina 4. Frigoríficos 5. Produção agropecuária I. Título

CDD 636.213

"Permitida a cópia total ou parcial deste documento, desde que citada a fonte - O autor" 
SHEMA ISRAEL

ADONAI ELOHENU

ADONAI EHAD

“...Recobra alma mía tu reposo

porque el Señor fue bueno contigo...

Salmo 116 (Acción de Gracias)

“...Al ir, van llorando, llevando las semillas;

Y vuelven cantando, trayendo las gavillas."

Salmo 126 (Canto del Regreso) 


\section{DEDICO}

A você Silvinha minha amada! Dádiva preciosa do Senhor em minha vida, por mais uma conquista e pelos dias de luta que ainda virão.

Che rohaihu'etereí... che kuñataĩ porã!

Ao papai Agustín que desde mitaí em Horqueta no Paraguay ia atrás dos bezerros nos brejos e à mamãe Fátima que desde pequena ia pra lavoura plantar de tudo; ainda hoje vocês acreditam e me mostram a força da terra, de plantar e colher! Por todas as orações, palavras de ânimo e coragem que me apoiaram neste tempo, principalmente por terem me dado a Palavra de Deus meu sustento maior.

Aos meus irmãos, Gabri, meu gêmeo e Migui, nosso maninho - meus compañeros, pelo amor, carinho e orações que me animaram a enfrentar todas as dificuldades deste tempo e da distância de casa. Meus amigos inseparáveis.

Aos meus avós paternos, abuelo Julio y abuela Estelvina, o suor de vocês em terras paraguayas permitiu que eu chegasse aqui. Muitas saudades...

Aos meus avós maternos, minha vozinha amada, vó Zélia, pelo teu amor mais doce, pela sabedoria e paciência que me ensinam muito e me faz te admirar cada dia mais, e ao senhor vovô, Ramão Alves de Souza, por ter me passado o gosto pelo sistema dos antigos, do gado, da terra, do mato, foi um tempo curto, mas inesquecível! Que saudade! O trabalho de vocês nas fazendas São Geraldo em Bela Vista (MS) e Santa Fé das Cachoeiras em Ponta Porã (MS), trouxeram-me até aqui para registrar neste papel o suor de cinco gerações no guatambu da enxada e na baldrana do arreio.

A nossa classe produtora! 


\section{AGRADECIMENTOS}

A ti Senhor, pela tua Palavra que me anima e por permitir que este tempo se cumpra em minha vida; sem Ti isto seria o mesmo que nada.

Ao professor Dr. Eduardo F. Delgado, meu maior mestre e um precioso amigo, pela riqueza de conhecimento e sabedoria de vida que levarei sempre comigo, pela paciência, confiança e palavras que seguem me incentivando.

Ao pesquisador Dr. Gelson Luís Feijó da Embrapa Gado de Corte, por sua admirável competência e especialmente as longas horas de conversa que me orientaram no início desta jornada.

Ao professor Dr. Dante P. Duarte Lanna (ESALQ), pela confiança e proposta deste trabalho e por ter facilitado nossas ações junto ao grupo frigorífico; e ao professor Dr. Sérgio De Zen (ESALQ) pelo apoio através do CEPEA, ambos enriqueceram este trabalho com sugestões geniais.

A Dra. Claudia Paro de Paz (APTA Ribeirão Preto) pelo apoio imensurável nas análises estatísticas.

Aos professores Dr. Mateus Paranhos da Costa (Unesp Jaboticabal), Dra. Carmen Contreras Castillo (ESALQ), Dr. Albino Luchiari Filho (FZEA); e ao pesquisador Dr. Guilherme Alleoni (IZ) por contribuírem em minha formação.

Aos professores Dr. Pedro Eduardo de Felício (Unicamp) e Dr. Paulo Roberto Leme (FZEA) sempre dispostos a colaborar com suas vastas experiências e conhecimentos.

Aos professores Dr. Raul Machado Neto (ESALQ) e Raul Dantas D'Arce (ESALQ), verdadeiros mestres no saber e na relação humana. 
Ao professor Dr. Nelcindo N. Terra (UFSM) e ao Dr. Rogério M. Lemes de Campos (Universidad Complutense de Madrid), meus amigos e primeiros mentores em ciência de carnes, motivadores desmedidos no crescimento científico-profissional de seus alunos.

Aos colegas do Laboratório de Anatomia e Fisiologia Animal (LAFA), em especial ao Eric F. Leonardo pelos bons anos de convívio, apertos e companheirismo e a Dra. Aparecida Carla Pedreira por compartir tempo e conhecimento em nossos experimentos do LAFA.

Aos colegas do Laboratório de Nutrição e Crescimento Animal (LNCA), em especial a Tuca sempre prestativa e atenciosa.

Ao Rodrigo Goulart (companheirão!), Laudi Cunha Leite, Daniel de Paula, Marconi B. Teixeira e José César da Cruz meus companheiros da República Viola Quebrada. E aos colegas da PPG Ciência Animal e Pastagens: Paulo Correia, Marco Antonio da Gama, Vicente Turino, Patrick Schmidt, José L. Ribeiro, J. Lucas Mari, Clayton Q. Mendes, Laerte e Clarissa Cassol, Eduardo Eifert e Daniel Sarmento, bons companheiros e excelentes profissionais.

Ao Alan, Fernandão, Renata e Fernandinho - equipe de informática do CEPEA - pela valorosa ajuda na execução deste trabalho.

A Universidade Federal de Santa Maria (UFSM) e a Escola Superior de Agricultura "Luiz de Queiroz" (ESALQ), minhas referências.

Ao CNPq pela concessão da bolsa de estudos. 


\section{SUMÁRIO}

Página

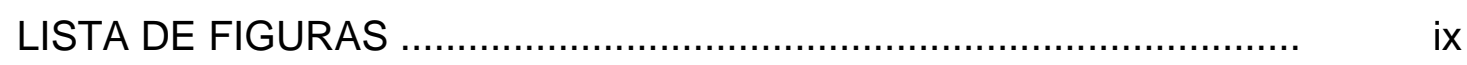

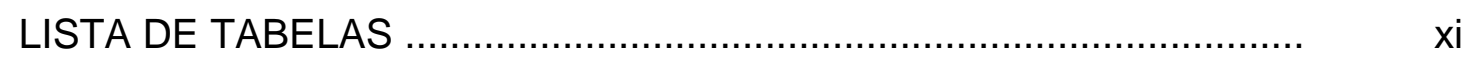

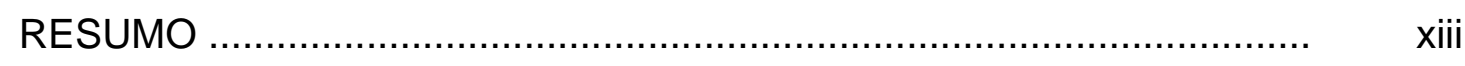

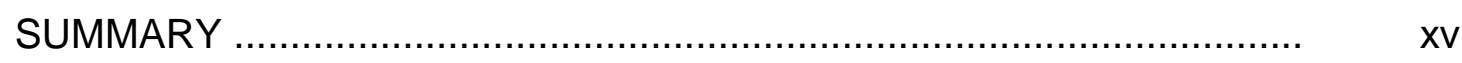

1 INTRODUÇÃO .................................................................. 1

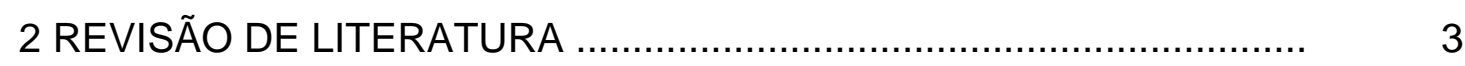

2.1 Caracterização da produção bovina no Brasil ................................ 3

2.1.1 Composição do rebanho bovino brasileiro ................................. 3

2.1.2 Ciclicidade da produção de carne bovina ................................ 5

2.2 Aspectos relacionados à carcaça bovina ....................................... 7

2.2.1 Crescimento animal e composição da carcaça .............................. 7

2.2.2 Qualidade da carcaça bovina ............................................ 8

2.3 Perspectivas para a produção bovina nacional .............................. 12

2.3.1 Cenário de comercialização interno e externo ........................... 12

3 MATERIAL E MÉTODOS ....................................................... 15

3.1 Origem dos dados ........................................................ 15

3.2 Coleta das informações ...................................................... 15

3.3 Sistematização das informações ............................................. 16

3.4 Análise estatística .......................................................... 17

3.5 Descrição das informações .................................................. 18

4 RESULTADOS E DISCUSSÃO ........................................... 19

4.1 Caracterização regional dos abates ....................................... 19

4.2 Características de qualidade da carcaça.................................... 25 


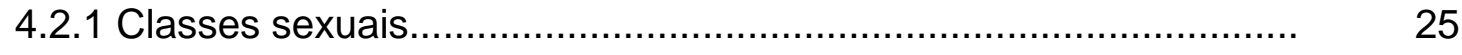

4.2 .2 Idade cronológica ....................................................... 29

4.2 .3 Acabamento ................................................................... 34

4.2.4 Peso da carcaça ................................................................ 41

5 CONCLUSÕES ................................................................... 47

REFERÊNCIAS BIBLIOGRÁFICAS ......................................... 48 


\section{LISTA DE FIGURAS}

Página

1 Ilustração gráfica da unidade federativa de origem dos bovinos abatidos, conforme a localização geográfica dos frigoríficos

2 Microrregiões do Brasil com a localização das unidades frigoríficas e as principais microrregiões fornecedoras de bovinos no período estudado

3 Evolução temporal da taxa mensal de abate de machos e fêmeas em quatro unidades frigoríficas localizadas nos estados de MS, SP, GO, MG

4 Evolução temporal do abate mensal de machos em quatro unidades frigoríficas localizadas nos estados de MS, SP, GO e MG

5 Evolução temporal da taxa mensal de abate de novilho (até quatro dentes) e boi (seis e oito dentes) em relação ao total de machos castrados abatidos, em quatro unidades frigoríficas localizadas nos estados de MS, SP, GO e MG 
6 Evolução temporal do abate mensal de novilho (até quatro dentes) e novilho com grau de acabamento 3 em quatro unidades frigoríficas localizadas nos estados de MS, SP, GO, MG

7 Evolução temporal do abate mensal de novilho (até quatro dentes) com grau de acabamento 3 em quatro unidades frigoríficas localizadas nos estados de MS, SP, GO e MG

8 Evolução temporal da taxa de abate de novilho (até quatro dentes) com grau de acabamento 3 em relação ao novilhos abatidos em quatro unidades frigoríficas localizadas nos estados de MS, SP, GO e MG

9 Distribuição das classes de peso para machos castrados jovens (até quatro dentes) e adultos (seis e oito dentes) em quatro unidades frigoríficas localizadas nos estados de MS, SP, GO, MG de janeiro de 2001 a agosto de 2003

10 Distribuição das classes de peso das carcaças de novilhos com acabamento 3. Dados coletados entre janeiro de 2001 a agosto de 2003 em quatro unidades frigoríficas localizadas nos estados de MS, SP, GO, MG 


\section{LISTA DE TABELAS}

Página

1 Os principais rebanhos de bovinos do Brasil por mesorregião

2 Origem geográfica dos bovinos abatidos na unidade frigorífica de MS

3 Origem geográfica dos bovinos abatidos na unidade frigorífica de SP

4 Origem geográfica dos bovinos abatidos na unidade frigorífica de GO

5 Origem geográfica dos bovinos abatidos na unidade frigorífica de MG

6 Percentagem das classes sexuais em relação ao volume anual de abate em três anos consecutivos de operação, por unidade frigorífica de acordo com sua localização geográfica 
7 Percentagem de machos castrados com até quatro incisivos permanentes $(\mathrm{J})$ e machos castrados com seis e oito incisivos permanentes $(A)$ em relação ao total de machos castrados abatidos em três anos consecutivos de operação, por unidade frigorífica de acordo com sua localização geográfica

8 Percentagem dos graus de acabamento de carcaças de novilhos (até quatro dentes) em três anos consecutivos de operação, de janeiro de 2001 a agosto de 2003, por unidade frigorífica de acordo com sua localização geográfica 


\title{
CARACTERÍSTICAS DE CARCAÇAS BOVINAS OBTIDAS POR FRIGORÍFICOS NA REGIÃO CENTRAL DO BRASIL, UM RETRATO ESPACIAL E TEMPORAL
}

RESUMO

\author{
Autor: RAFAEL FERREIRA SORIA \\ Orientador: EDUARDO FRANCISQUINE DELGADO
}

As características de carcaças bovinas relacionam-se indiretamente com aspectos de qualidade da carne bovina, bem como permitem verificar limitações e progressos do sistema produtivo. Portanto, um retrato atual daquelas características em âmbito regional e suas variações anuais e plurianuais é ferramenta essencial na transferência de informação para o gerenciamento e sustentabilidade da cadeia de carne bovina. A análise do banco de dados de um grupo frigorífico com unidades industriais localizadas no Sudoeste de Mato Grosso do Sul, Meio-Oeste de São Paulo, Noroeste de Goiás e Triângulo Mineiro, importantes regiões para a pecuária nacional, durante 31 meses de operação industrial (janeiro de 2001 a agosto de 2003), permitiu descrever as características das carcaças bovinas nessas regiões geográficas, entre épocas do ano e entre os anos. Cada unidade foi abastecida principalmente por fornecedores do próprio estado e as regiões que mais negociaram estavam nas proximidades das unidades, exceto a unidade frigorífica de SP onde grande parte do abate teve origem no Leste de MS. As fêmeas totalizaram 13,16\% dos abates e houve oferta crescente no período a partir do segundo semestre de 
2002 com pequena redução no abate de machos, destes 75,96\% eram castrados e 10,88\% inteiros. A região teve impacto na oferta de características como classe sexual, maturidade e grau de acabamento para machos castrados, contudo houve um padrão predominante em todas as unidades em volume e freqüência de oferta, com carcaças de machos castrados de 6 a 8 dentes compondo $61,6 \%$ dos abates do grupo. A unidade de $\mathrm{GO}$ foi a que mais abateu machos inteiros, totalizando 36\% dos abates. A unidade de MG se destacou na proporção de machos castrados até 4 dentes (novilhos) em relação aos machos castrados abatidos, com uma média de 25\%. O abate de novilhos com grau de acabamento 3 (espessura de gordura entre 3 e $6 \mathrm{~mm}$ ) representaram 7,9\% dos abates, destacando-se MS e SP em volume de abate e proporção, com 2/3 dos novilhos atingindo este acabamento. A oferta de carcaças de novilhos e de novilhos com grau de acabamento 3 ocorreu em dois momentos do ano, de abril a junho e de agosto a novembro. No período estudado, a oferta de novilhos com grau de acabamento 3 não acompanhou a oferta de novilhos, variando com a região, sendo que a unidade de SP foi abastecida de forma mais regular. O peso médio de abate dos machos castrados foi de $264,4 \mathrm{~kg}$ (DP $\pm 15,2 \mathrm{~kg}$ ), equivalente a 17,6@ e à medida que os animais avançaram na idade aumentou a freqüência de carcaças pesadas. Carcaças acima de 18@ corresponderam à $40,6 \%$ dos adultos e $22,9 \%$ dos novilhos. Para os novilhos com acabamento 3 a faixa de peso predominante foi de $16-17 @$ em todas unidades, exceto em MG onde a classe de peso predominante esteve acima de 18@. 


\title{
BEEF CARCASS CHARACTERISTICS FROM MEAT INDUSTRIES IN THE CENTRAL REGION OF BRAZIL, A SPATIAL AND TEMPORAL PICTURE
}

SUMMARY

\author{
Author: RAFAEL FERREIRA SORIA \\ Adviser: EDUARDO FRANCISQUINE DELGADO
}

Beef carcass characteristics are indirectly related with meat quality and helps to identify limitations and progresses of the productive system. Wherefore establishing a picture of such characteristics and their annual and pluriannual variations represents an essential tool on information transference for the beef supply chain management and sustainability. This study was based on data from a beef industry composed by four unities located in important Brazilian regions for beef cattle production (Southeast of Mato Grosso do Sul State, Middle-West of São Paulo State, Northwest of Goiás State and at Triângulo Mineiro Region of Minas Gerais State), during 31 months (January, 2001 to August, 2003). Database analysis allowed to describe beef carcass characteristics within periods over a year and among years of industrial activity. Producers from regions close to the plants inside the same state were their main suppliers, except for the unity in the São Paulo State where a large number of animals came from East of Mato Grosso do Sul State. Castrated males represented $75.96 \%$ of total slaughter, intact males $10.88 \%$ and females $13.16 \%$. The number of female slaughtered increased over the second 
semester of 2002 reducing thus the proportion of male slaughtered. There was an influence of the supplying region on sexual condition, maturity and finishing of castrated males with up to four permanent incisors (steers). However, the main carcass pattern in all unities, when considering number and frequency, was castrated males with at least six permanent incisors, representing $61.6 \%$ of total slaughter. The Goiás State's plant slaughtered the highest number of intact males with $36 \%$ of its total slaughter. The Minas Gerais State's plant registered the highest proportion of steers when considering castrated male slaughtered, averaging 25\% of its total. Steers with finishing grade 3 (fat thickness 3 to $6 \mathrm{~mm}$ ) represented $7.9 \%$ of all carcasses, distinguishing Mato Grosso do Sul and São Paulo States' plants in which two-thirds of steers reached that finishing grade. The supply of steers finishing grade 3 had two peaks with increasing offer over the years, from April to July and from August to November. The number of these carcasses did not follow steers supply with a regional influence. São Paulo State plant was the only one regularly supplied with properly finished steers. The average carcass weight was $264.4 \mathrm{~kg}$ (SE $\pm 15.2 \mathrm{~kg}$ ). Heavier carcasses were obtained only when animals slaughtered grew older with frequencies of carcass weight over $269.9 \mathrm{~kg}$ corresponding to $40.6 \%$ of the older castrated males and $22.9 \%$ of the steers. The most frequent carcass weight ranged from 240 to $254.9 \mathrm{~kg}$ for steers with finishing grade 3 in all plants, except for the one at Minas Gerais State where the predominant weight range was over $269.9 \mathrm{~kg}$. 


\section{INTRODUÇÃO}

$\mathrm{Na}$ segunda metade da década de 90, a absorção tecnológica pela cadeia de produção bovina acelerou-se com a estabilização da economia. Os rendimentos especulativos deixaram de ser atrativos com a estabilidade dos preços agrícolas e a redução das margens de lucro de produtores rurais e frigoríficos exigia investimento em tecnologias de gestão e produção, como meio de garantir a rentabilidade de suas atividades (Cezar et al., 2004; De Zen, 1999).

Esta remodelagem da cadeia bovina brasileira, detentora do maior rebanho comercial com cerca de 195,5 milhões de animais (Instituto Brasileiro de Geografia e Estatística - IBGE, 2005) e de um dos menores custos de produção aliados às recentes conquistas sanitárias, têm permitido ao país destacar-se entre os principais fornecedores de carne, reconhecidamente pela capacidade de abastecimento quantitativo a preços extremamente competitivos no mercado internacional (Cezar et al., 2004; Pineda, 2004).

Contudo, o processo de adoção tecnológica é lento comparado ao setor de suínos e aves. Os índices nacionais apesar de terem se elevado são ainda inferiores a países com tradição no setor. A taxa de abate demonstra a evolução, passando de 16,43\% em 1994 para 20,52\% em 2002, entretanto aquém dos 24\% na Argentina, 36\% na Austrália e 33\% nos EUA (Cezar et al., 2004; Resende, 2003).

A extensão territorial, as condições edafo-climáticas que variam entre macro e micro regiões, entre épocas do ano e anos consecutivos, os diferentes níveis tecnológicos os quais somados a inúmeros fatores (e.g. tomada de 
decisão, desvalorização cambial, demanda internacional, etc...) interagem, afetando a produção e oferta de bovinos enviados para abate e refletindo diretamente na diversidade de carcaças.

No setor frigorífico, a necessidade de regular a ociosidade industrial, juntamente com o processo de oferta e procura, e possíveis "filtros de compra" praticados pela indústria influenciam na diversidade de bovinos abatidos. Assim, a freqüência de características específicas de qualidade de carcaças como idade, acabamento e condição sexual, pode apresentar variações entre períodos e regiões em detrimento da necessidade de escala, tornando os aspectos de qualidade inconsistentes na rotina operacional.

É evidente a descoordenação e desorganização da cadeia (De Zen, 1999; Favaret Filho \& De Paula, 1997; Pedroso, 2000; Pineda, 1997). Esta realidade retarda a adoção de avanços tecnológicos que permitam explorar a diversidade e a qualidade do que é produzido. Amaral (2000) alerta sobre a integração das informações, como aspecto estratégico de eficiência, sendo uma condição sine qua non para abastecer o mercado interno e externo de forma eficiente.

A etapa inicial do processo de integração de informações e ações para abastecimento de possíveis demandas envolve a obtenção de um retrato da situação atual da qualidade de carcaça, que permitam estimar a qualidade da carne produzida, bem como a sustentabilidade e eficiência da cadeia produtiva. Com o objetivo de verificar a variação entre regiões (espacial) e épocas (temporal) de características das carcaças bovinas diretamente relacionadas com sua qualificação, foram obtidas, sistematizadas e descritas informações de extenso banco de dados, da atividade industrial plurianual de um grupo frigorífico de relevância no cenário nacional. 


\section{REVISÃO DE LITERATURA}

\subsection{Caracterização da produção bovina no Brasil}

\subsubsection{Composição do rebanho bovino brasileiro}

Nos últimos 40 anos tem se alterado a distribuição do rebanho bovino no território nacional, com a concentração no eixo centro-sul deslocando-se progressivamente para o eixo centro-norte do país. E esta reconfiguração devese principalmente ao menor preço das terras nas novas fronteiras de produção agropecuária (FNP Consultoria, 2002; IBGE, 2005; Santiago, 1970).

As regiões do Norte Matogrossense, Sudeste Paraense e Leste Rondoniense, já estão entre as principais regiões pecuárias do país (Tabela 1).

Atualmente o rebanho bovino brasileiro está estimado em 195,5 milhões de cabeças, sendo $20 \%$ com finalidade de produção leiteira e $80 \%$ para corte. A população de zebuínos e seus cruzamentos representam cerca de $80 \%$ do efetivo nacional (IBGE, 2005; Josakhian, 1999). As raças de origem européia têm aumentado sua participação nos rebanhos comerciais, especialmente na região central do país, pelas vantagens zootécnicas propiciadas pela heterose (Associação Brasileira de Inseminação Artificial, 2005; Fries, 1996; Restle et al., 2000).

As peculiaridades regionais do Brasil são fatores importantes que compõem o perfil dos animais abatidos. Barbosa \& Bueno (2000) mostraram que o número de vacas ordenhadas representa menos de $9 \%$ do rebanho nacional e ao redor de $25 \%$ do leite produzido no Brasil provém de sistemas 
mistos de leite e carne, equivalente a $18 \%$ das fazendas na região Sudeste e 45\% no Centro-Oeste. Em algumas regiões brasileiras, como nos estados de Goiás e Minas Gerais onde a atividade leiteira é mais expressiva, há predomínio de raças leiteiras nos cruzamentos, resultando na produção significativa de carne a partir deste biótipo (Madalena, 2001; Marcatti Neto et al., 2000).

Tabela 1. Os principais rebanhos de bovinos do Brasil por mesorregião

\begin{tabular}{ccc}
\hline Mesorregião Brasileira & Unidade Federativa & Número de Cabeças \\
\hline Norte Matogrossense & MT & 9.384 .573 \\
Sudeste Paraense & PA & 8.885 .454 \\
Leste de Mato Grosso do Sul & MS & 8.303 .153 \\
Sul Goiano & GO & 7.796 .884 \\
Leste Rondoniense & RO & 7.873 .600 \\
Sudoeste de Mato Grosso do Sul & MS & 7.111 .256 \\
Ocidental do Tocantins & TO & 6.181 .287 \\
Triângulo Mineiro/Alto Paranaíba & MG & 5.898 .970 \\
Centro Norte de Mato Grosso do Sul & MS & 5.402 .075 \\
Nordeste Matogrossense & MT & 5.049 .854 \\
Sudoeste Riograndense & RS & 4.880 .928 \\
Sudoeste Matogrossense & MT & 4.387 .567 \\
Noroeste Goiano & GO & 4.377 .759 \\
Pantanal Sul Matogrossense & MS & 4.167 .337 \\
Centro Goiano & GO & 3.844 .256 \\
Centro-Sul Matogrossense & MT & 3.006 .020 \\
Centro Sul Baiano & BA & 2.795 .511 \\
Sudeste Matogrossense & MT & 2.785 .704 \\
Presidente Prudente & SP & 2.708 .121 \\
Noroeste Riograndense & RS & 2.642 .001 \\
\hline
\end{tabular}

Fonte: IBGE Diretoria de Pesquisas, Coordenação de Agropecuária, Brasil 2005

A carne de fêmeas bovinas dependendo do ano pode atingir $40 \%$ do total consumido no país (Perobelli et al., 1995). A taxa de abate de fêmeas vem 
aumentando nos últimos seis anos e em 2003 estava estimada em 46\% dos abates (FNP Consultoria, 2003).

Animais como vacas, touros e bois com mais de três anos representam respectivamente, $36,6 \%, \quad 1,36 \%$ e $1,96 \%$ do rebanho brasileiro (FNP Consultoria, 2003). Conforme o estado e localização regional da planta frigorífica, pode haver uma maior ou menor oferta destas categorias e a necessidade de incorporá-las à linha de produção por razões econômicas.

\subsubsection{Ciclicidade da produção da carne bovina}

A produção bovina no Brasil está fundamentada na utilização das pastagens, concentrando a maior parte do rebanho em clima e solos tropicais. Predominam pastagens cultivadas do gênero Brachiaria sp, em geral sem recomposição da fertilidade do solo há pelo menos 30 anos e marcadas por déficit hídrico e variação anual de temperatura, próprios de sistemas tropicais, impedindo a disponibilidade uniforme de forragens durante o ano (Aguiar, 1998; Costa et al., 2001; Faria, 1999; IBGE, 2003; Maraschin, 2001). Conseqüentemente a estacionalidade na produção de carne decorre da estacionalidade da oferta de alimento para os bovinos.

Em sistemas baseados exclusivamente em pastagens a curva de crescimento dos animais não é linear (Boin \& Tedeschi, 1996). Durante o período de seca na região central do país, ocorre a diminuição da produtividade e qualidade das pastagens comprometendo o desempenho animal pelas limitações nutricionais impostas (Corsi, 1994; Rosa, 2001). Os animais realizam um bom crescimento em meses favoráveis do ano, durante a primavera/verão e parte do outono e perdem peso em fins do outono e durante o inverno (Müller \& Primo,1986). Estas condições definem a oferta de bovinos no mercado, com um primeiro semestre marcado por maior oferta (safra) e um segundo semestre de menor oferta (entressafra), caracterizando a ciclicidade da atividade em um ano, denominado de ciclo curto (Almeida \& Azevedo, 1996; Haddad, 1999). 
Esta premissa deve-se em parte pela perpetuação do conceito extrativista da produção bovina, ao estabelecer a atividade em áreas com limitação para culturas, favorecendo a resistência a mudanças nos procedimentos de manejo de pastagens, aceitando-se baixos índices de produtividade com naturalidade (Corsi, 1994). Estima-se que apenas na região do Cerrado, entre $50 \%$ e $80 \%$ dos 50 milhões de hectares de pastagens apresentam algum nível de degradação (Barcellos, 1996; Vieira \& Kichel, 1995).

No Brasil, são recomendações antigas a adubação de pastagens e irrigação durante o inverno, conforme Pereira et al. (1966) citados por Corsi (1994) e o confinamento como meio de ofertar animais durante a entressafra, segundo Tundisi et al. (1966) citados por Boin \& Tedeschi (1996).

A variação estacional que determinava preço pago ao produtor até $30 \%$ superior durante a entressafra motivou a intensificação dos sistemas de produção. A exploração intensiva de pastagens, suplementação estratégica, uso de pastagens de inverno e a prática de confinamento, na tentativa de promover o crescimento linear dos animais por anular o efeito negativo do estresse e abater os animais em idade jovem, contribuíram para reduzir a estacionalidade e minimizar o diferencial de preços entre 8 a 12\% (Andrade, 1988; Balsalobre et al., 2002; Bürgi \& Pagotto, 2002; Corsi, 1994; Vilela et al., 2004).

A bovinocultura também é marcada por um ciclo longo ou plurianual que ocorre a cada 6 a 7 anos e se caracteriza por uma maior ou menor oferta de bovinos machos destinados ao abate, em decorrência do número variável de matrizes que compõe o rebanho brasileiro (Almeida \& Azevedo, 1996; Haddad, 1999).

Estas flutuações cíclicas e sazonais são os fatores estruturais para a formação de preço pago ao produtor, juntamente com as tendências e variações irregulares do mercado consumidor. A concorrência com carnes de outras espécies também influencia o preço, porém em menor intensidade (Instituto Euvaldo Lodi - IEL, 2000). 


\subsection{Aspectos relacionados à carcaça bovina}

\subsubsection{Crescimento animal e composição da carcaça}

Crescimento é definido pelo acréscimo de osso, proteína e gordura e é mensurado pela mudança no peso vivo (Owens et al., 1995). O crescimento contínuo, sem interrupção, é uma concepção teórica e expresso por uma curva sigmóide. A eficiência do crescimento de bovinos depende de fatores como peso, idade, tamanho adulto, raça, genética, nutrição e sexo (Koch et al., 1982; Oltjen \& Garret, 1988; Owens et al., 1993).

Os tecidos corporais possuem crescimento dinâmico e ímpetos de crescimento e maturação fisiológica diferenciados. Iniciando-se pelo tecido nervoso e seguido pelo ósseo, muscular e adiposo, esta progressão implica em diferentes exigências nutricionais conforme a fase de crescimento animal (Owens et al., 1993 e 1995).

Na puberdade com a cessação do crescimento ósseo e já tendo ocorrido a maior parte do desenvolvimento da musculatura, há a intensificação do acúmulo de gordura na carcaça. Quando o animal atinge o peso adulto o acréscimo de massa muscular é nulo e o ganho de peso passa a ser composto exclusivamente por gordura (Allen, 1990; Owens et al., 1993 e 1995).

Restrições alimentares severas, de nutrientes específicos (e.g. proteína) e/ou ocorrendo no final da fase pré-púbere ou logo após puberdade podem causar alterações irrecuperáveis no crescimento animal. Contudo, um certo nível de restrição, ainda que retarde o crescimento, favorece maior ganho de peso após realimentação. Este crescimento acelerado, superior ao contínuo e conhecido como crescimento compensatório, pode afetar a composição da carcaça e está relacionado a estacionalidade de produção de pastagens (Allen, 1990; Owens et al., 1993; Villares, 1995). 
Em sistemas de pastagens com maiores taxas de lotação, os animais precisaram de mais tempo para atingir o peso de abate (Euclides \& Euclides Filho, 2001). Considerando a obtenção de carcaças com peso e composição semelhantes, bovinos da raça Nelore, quando não suplementados no período seco precisam ser abatidos em idade avançada (35,3 meses) em relação a animais suplementados na primeira ou segunda seca (30,6 e 28,7 meses) ou recebendo suplementação na primeira seca e confinamento na segunda $(22,6$ meses) (Euclides Filho et al., 1997a). Portanto, a curva de crescimento e a eficiência bionutricional são características de forte impacto na eficácia global da cadeia da carne bovina no Brasil (Euclides Filho, 2000).

A redução da quantidade ou qualidade das pastagens tem repercussão maior em bovinos na fase de terminação. Nesta etapa a composição do ganho é representada principalmente pela deposição de gordura na carcaça. É o processo mais eficiente do ponto de vista energético, porém requer do sistema de produção maior aporte de nutrientes, pois é necessário quatro vezes mais energia para depositar um grama de tecido adiposo comparado ao tecido muscular (Owens et al., 1993; Restle et al., 2001).

A gordura corporal distribui-se em depósitos durante o desenvolvimento pós-natal, na seguinte ordem: cavitário e visceral, intermuscular, subcutâneo e intramuscular. A quantidade acumulada em cada sítio é influenciada pelo tipo biológico, estado fisiológico e aporte nutricional, sendo o componente de carcaça mais variável e de maior influência no rendimento (Charles \& Johnson, 1976; Pearson, 1966; Peron et al., 1993).

Os indivíduos devem ser capazes de direcionar grandes quantidades de energia da dieta para produção de músculos, produzindo carcaças com alta proporção de carne comercializável (Galvão et al., 1991). Tipos biológicos com diferentes taxa de crescimento, tamanho adulto e conformação corporal, ajustados a um peso de carcaça, apresentaram diferença na porcentagem de cortes, composição dos cortes e na quantidade de gordura pélvica e renal da carcaça, característica de maior variação (Koch et al., 1982). 
Assim, características relacionadas a aspectos qualitativos de carcaças bovinas são alteradas por decisões de manejo, seleção genética e cruzamentos, nível energético e sistemas de terminação (Peron et al., 1995; Perotto et al., 1999).

\subsubsection{Qualidade da carcaça bovina}

Um conceito estabelecido há muitos anos, refere-se às características almejadas nas carcaças bovinas: o máximo de músculos e o mínimo de ossos com quantidade adequada de gordura. $O$ estudo de carcaças permite avaliar a qualidade do produto final de um sistema de produção (Costa et al., 2002). E segundo Delgado (2000b), a qualidade da carcaça relaciona-se indiretamente com aspectos de qualidade da carne bovina.

O valor comercial das carcaças bovinas é determinado por um conjunto de características, dentre as quais: peso, gordura de cobertura, rendimento e marmoreio (gordura intramuscular) (Perotto et al., 1999). Em sistemas de tipificação de carcaças, a quantidade e distribuição de gordura na carcaça são fatores importantes na determinação de seu valor (Peron et al., 1993).

A variação de peso da carcaça é de relevância econômica aos frigoríficos, ao considerar que materiais de pesos diferentes na linha de abate requerem a mesma mão-de-obra e tempo de processamento na desossa (Costa et al., 2002).

O peso da carcaça é determinado pela indústria. Nos EUA o peso requerido varia de 250 a 430 kg, ou 16 a 28@ (Blach, 2003). Nos frigoríficos nacionais ocorre penalização das carcaças com peso inferior a 230 kg (15@). Por outro lado, em algumas regiões do Rio Grande do Sul, carcaças acima de 180 kg (12@) e com pelo menos 3 mm de gordura de cobertura estão sendo aceitas por estarem associadas com bovinos abatidos ao redor dos 14 meses, produzindo carne de qualidade quanto às características organolépticas (Costa et al., 2002; Restle \& Vaz, 2003). A espessura da gordura de cobertura tem 
recebido maior importância, evitando-se carcaças com cobertura abaixo de 3 $\mathrm{mm}$ e acima de $6 \mathrm{~mm}$ (Restle \& Vaz, 2003).

Um produto com espessura menor do que $3 \mathrm{~mm}$ sofre escurecimento da parte externa dos músculos pelo frio das câmaras frigoríficas nas primeiras 24 horas, além do encurtamento excessivo das fibras musculares pela maior velocidade de resfriamento, conhecido como "cold shortening", que afeta negativamente a maciez da carne (Junqueira \& Alleoni, 1998; Kuypers, 2000).

Por outro lado, a indústria na tentativa de reduzir o custo operacional busca processar carcaças mais pesadas, porém pesos elevados implicam numa maior quantidade de gordura subcutânea que reduz o rendimento da porção comestível (Charles \& Johnson, 1976; Hedrick et al., 1965; Nour et al., 1983). Apesar deste fato não representar problema usual à cadeia brasileira, cabe ressaltar que carcaças com muita gordura subcutânea sofrem toalete mais intenso na linha de abate, o que representa prejuízo duplo ao produtor, devido ao aumento do custo de produção durante a terminação pela menor eficiência biológica em acumular gordura e em segundo lugar pela perda do peso da carcaça, uma vez que o excesso de gordura é removido antes da pesagem.

Uma auditoria realizada em 1995 no setor americano de carne bovina verificou que o excesso de gordura externa e o marmoreio insuficiente, estavam entre as dez principais preocupações, evidenciando o valor econômico destas características de qualidade de carcaça para tal cadeia (Boleman et al., 1998).

Essas variações podem ser explicadas pelos tipos biológicos. Novilhos europeus de origem britânica têm significativamente mais gordura de marmoreio que os de origem continental, assim como animais mais velhos (Short et al., 1999). Além disto, o abate seqüencial de novilhos de origem britânica dos 16 aos 22,5 meses de vida, evidencia que a espessura de gordura e o marmoreio aumentam significativamente com o tempo de alimentação, existindo uma elevada correlação entre ambas (May et al., 1992). 
A comparação das carcaças de novilhos ${ }^{1}$ oriundos de reprodutores da raça Nelore e de raças européias continentais e britânicas em fêmeas meio sangue Angus/Hereford, quando o abate é realizado a uma mesma idade (426 dias), revela que os produtos de origem britânica têm maior espessura de gordura, seguidos dos cruzados Nelore e por último as raças continentais (Wheeler et al., 1996). Quanto a área de olho de lombo na $12^{\mathrm{a}}$ costela, ocorre uma inversão da ordem anterior. Ajustando o abate a um mesmo grau de acabamento (1,2 cm de gordura subcutânea) as britânicas precisam de menos dias que a raça Nelore e as continentais são as mais tardias. O marmoreio dos cruzados Nelore é menos abundante que as demais raças e esta diferença aumenta quando os novilhos são abatidos num mesmo ponto de acabamento. Estes resultados demonstram as diferenças nas taxas de crescimento (os novilhos de origem britânica atingem maturidade mais cedo seguidas pelos novilhos com sangue Nelore e por fim os de origem continental) e como esta determina diferença nas características das carcaças. Nenhuma raça comportou todas as características de carcaça desejáveis.

Em estudos conduzidos no Brasil, Euclides Filho et al. (1997b) não encontraram diferenças entre machos castrados Nelore e cruzados Nelore/Charolês, Nelore/Fleckvieh e Nelore/Chianina, para alguns atributos de carcaças, exceto que animais Nelore tendem a produzir carcaças com mais gordura quando comparadas a cruzamentos com raças européias continentais. Estes resultados são corroborados por Berndt et al. (2001), onde tourinhos Nelore, quando comparado aos animais Angus/Nelore e Simental/Nelore tenderam a atingir 3 e $8 \mathrm{~mm}$ de espessura de gordura com menor peso vivo.

Quanto ao sexo, as carcaças de animais inteiros são mais pesadas, de melhor conformação e maior proporção de músculos, porém apresentam menor quantidade de gordura de cobertura e intramuscular e maior velocidade de maturação fisiológica comparado aos castrados (Restle et al., 1996).

\footnotetext{
${ }^{1}$ O estudo comparou dez raças, aqui são comparados os resultados dos reprodutores da raça Nelore com as raças Charolês, Gelbvieh e Piemontês (origem continental) e Angus e Hereford (origem britânica)
} 
Fêmeas de descarte normalmente possuem peso vivo menor, intensa deposição de gordura, menor musculosidade e conseqüentemente menor porção comestível e maior proporção de ossos na carcaça em relação aos novilhos (Perobelli et al., 1995; Restle et al., 1990). As fêmeas descartadas são aquelas que deixam de interessar aos sistemas de produção por estarem desqualificadas, seja pela deficiência na produção, idade avançada e seleção. Estas geralmente precisam ser engordadas para alcançarem peso adequado ao abate.

\subsection{Perspectivas para a produção bovina nacional}

\subsubsection{Cenário de comercialização interno e externo}

A constatação de que vivemos “... num país onde tem boi que nunca viu gente e gente que nunca viu carne..." como afirmou o jornalista Joelmir Beting, aponta para condições favoráveis de produção de carne em larga escala e de potencial consumo interno.

No entanto, esta expectativa pode não se concretizar nos próximos anos frente à estimativa de queda na produção do rebanho em 2006 e 2007 e conseqüentemente no consumo médio de carne bovina pela população brasileira, em torno de $31 \mathrm{~kg}$, o menor nos últimos dez anos (Nehmi Filho, 2005).

O Brasil, porém, acumula vantagens que podem sustentar a bovinocultura no cenário econômico nacional e internacional, como o aumento na taxa de desfrute, a adoção de políticas sanitárias rígidas, a implantação de um sistema de rastreabilidade e o baixo custo de produção que colaboraram para elevar as exportações de carne bovina; em torno de $20 \%$ da produção de 2004 (Nehmi Filho, 2005).

Estas afirmações são corroboradas por projeções de organismos internacionais no aumento do consumo de carne entre 2,8 e 3,3\% nos países 
em desenvolvimento e de 0,6\% nos países desenvolvidos até 2020 (Delgado, 2000a), bem como a sustentação do Brasil durante a próxima década como o segundo maior exportador de carne bovina (Food and Agricultural Policy Research Institute, 2004).

O número crescente de países exportadores, altamente competitivos e eficientes, exige que as necessidades e individualidades dos mercados importadores, progressivamente menores, sejam conhecidas para assegurar a aceitação contínua de um produto (Azevedo, 1997; Estados Unidos, 2002).

A sustentabilidade do Brasil neste processo exige que internamente a cadeia de carne bovina supere obstáculos inerentes ao histórico da atividade. A necessidade de modernizar as relações entre os diversos segmentos, especialmente entre produtores e frigoríficos torna-se prioritária (Euclides Filho, 2004; Neves et al., 2001; Pineda, 1997), pois ao integrar objetivos comuns permitiria preservar os atuais clientes de carne com baixo valor agregado, como o mercado chileno e árabe que adquirem cortes do dianteiro, e adentrar em nichos exigentes agregando valor ao produto carne bovina brasileira. Em alguns países europeus, boa parte da carne consumida é proveniente de bovinos machos inteiros; mercados da Ásia como o coreano e o japonês têm preferência por teores elevados de gordura que exigem outras categorias de animais para atender tal demanda (Restle et al., 1997; Robin \& Hart, 2001).

Portanto, para atender as expectativas dos consumidores com eficiência é necessário transmitir as informações ao longo dos segmentos. A descoordenação da cadeia é demonstrada pela comercialização da carne fêmeas no país (Haddad, 1999). Em países desenvolvidos as fêmeas de descarte são destinadas a produção de carne industrializada, enquanto os cortes nobres provenientes dos melhores animais destinam-se à venda no varejo com valor diferenciado e informação sobre o produto a ser adquirido (Perobelli et al., 1995). Por outro lado, consumidor brasileiro ao adquirir qualquer carne bovina dispõe de informações escassas ou mesmo nulas, 
atribuindo-se valores similares entre produtos de qualidade desigual, como proveniente de vacas de descarte e de animais jovens.

A estratificação do mercado da carne bovina pode ser vantajosa à bovinocultura brasileira, permitindo atender a partir de um mesmo produto diversos clientes com hábitos alimentares diferenciados, mas este é um processo que depende primeiramente de informações que auxiliem na caracterização do produto nacional. 


\section{MATERIAL E MÉTODOS}

\subsection{Origem dos dados}

Este estudo foi conduzido a partir do banco de dados de um grupo frigorífico de relevância no cenário nacional, com participação expressiva na pauta de exportação de carne bovina e programa interno de qualidade de carne. O grupo frigorífico é composto por quatro unidades industriais de grande porte (capacidade máxima de abate entre 1.200 e 1.500 cabeças/dia), localizadas nas mesorregiões Sudoeste de Mato Grosso do Sul, Bauru em São Paulo, Noroeste de Goiás e Triângulo Mineiro/Alto Paranaíba em Minas Gerais.

As informações constam de 31 meses de atividade, referentes ao período de janeiro de 2001 a agosto de 2003. As informações do mês de julho de 2001 não estavam disponíveis e portanto não fazem parte dos dados analisados.

\subsection{Coleta das informações}

As carcaças com características homogêneas são organizadas em classes, conforme Sistema Nacional de Tipificação de Carcaças Bovinas publicada na Portaria №612 de 05/10/89. Este sistema apesar de não ser adotado no processo de comercialização, tornou-se base para classificação interna do grupo frigorífico, que leva em consideração classe sexual, idade cronológica, grau de acabamento, peso da carcaça. A conformação da carcaça não é avaliada.

Estas informações são coletadas na linha de abate por funcionários do frigorífico e eventualmente funcionários de apoio ao Serviço de Inspeção Federal (SIF) do Ministério da Agricultura, através da observação dos caracteres sexuais as carcaças são agrupadas em três classes sexuais: machos inteiros, machos castrados e fêmeas; a maturidade é determinada pela 
cronologia dentária verificando a presença dos dentes incisivos permanentes, originando cinco classes - dente leite: apenas dentição caduca; dois dentes: presença das pinças permanentes; quatro dentes: presença dos primeiros médios permanentes; seis dentes: presença dos segundos médios permanentes; e oito dentes: presença dos cantos permanentes; e as classes de acabamento baseiam-se na avaliação visual da quantidade e distribuição da gordura de cobertura na região das costelas, lombo e coxão, são cinco - 1 : gordura ausente $(0 \mathrm{~mm}) ; 2$ : gordura escassa $(1-3 \mathrm{~mm}) ; 3$ : gordura mediana (3 - $6 \mathrm{~mm})$; 4: gordura uniforme (6-10 mm) e 5: gordura excessiva (> $10 \mathrm{~mm}$ ).

$\mathrm{Na}$ seqüência cada meia-carcaça é pesada. As informações são agrupadas em lotes, conforme a procedência, dado pelo nome da propriedade rural, localidade de origem (município/distrito/estado) e condição sanitária individual das carcaças avaliadas pelo SIF.

Todos os parâmetros são registrados eletronicamente, através de leitor óptico de código de barras, específico para cada parâmetro e de balança eletrônica para registro do peso das carcaças. A partir destes dados é realizada automaticamente a classificação da carcaça por sistema interno do grupo frigorífico. Os registros coletados diariamente são transferidos à matriz da empresa para arquivo em banco de dados.

\subsection{Sistematização das informações}

A compilação, extração e transferência dos dados em formato texto foram conduzidas pelo departamento de informática da indústria, armazenados em três discos de mídia eletrônica e enviados ao Laboratório de Anatomia e Fisiologia Animal da Escola Superior de Agricultura "Luiz de Queiroz" (ESALQ) em Piracicaba, São Paulo. Houve a necessidade de transferência dos dados ao servidor do Centro de Pesquisa em Economia Avançada (CEPEA) da ESALQ.

Através de um gerenciador de banco de dados (SQL Server, versão 5.0) conduziu-se a verificação dos dados, desprezando-se carcaças com registros 
incompatíveis com aqueles coletados pela indústria na linha de abate. Os dados descartados representaram $0,15 \%$ do total de informações obtidas da indústria.

Os dados estavam organizados em colunas: número do lote, número do SIF de cada unidade frigorífica, data do abate, peso da meia-carcaça, classe sexual, maturidade, acabamento, classificação pelo sistema interno da indústria, condição sanitária, nome da propriedade rural, município e estado. Cada linha é referente a informações de cada meia-carcaça produzida. O montante destas informações representa mais de 62 milhões de dados.

Para o estudo desprezou-se o número do lote e classificação interna. As carcaças foram analisadas independente da condição sanitária.

Uma vez sistematizados, no momento de extrair os dados foi realizada programação em Delphi para evitar possíveis perdas de informações. Os dados foram extraídos do servidor em arquivos formato texto e armazenados em mídia digital para análise estatística das características de carcaça.

Para descrição das regiões fornecedoras os dados foram extraídos do servidor em planilhas eletrônicas e processados em computador de uso pessoal.

\subsection{Análise estatística}

O processamento dos dados foi realizado pelo procedimento PROC FREQ do programa computacional Statistical Analysis System (SAS Institute Inc., 2001) para descrição das freqüências e médias dos parâmetros de carcaça: classe sexual, maturidade, acabamento e peso.

A partir destes resultados optou-se pelo agrupamento em novas classes para apresentação e discussão dos resultados.

Durante a análise das freqüências foram "perdidas" $0,136 \%$ do total de meia-carcaças. A base do estudo foi conduzida com 2.612.722 carcaças. 


\subsection{Descrição das informações}

Os critérios adotados para o novo agrupamento deveram-se às reduzidas freqüências de algumas características.

As informações estão assim organizadas e descritas:

Classe Sexual: Machos Inteiros (MI), Machos Castrados (MC); Fêmeas $(\mathrm{F})$.

Idade: Jovens (J) - bovinos de até quatro dentes (4D); Adultos (A) bovinos de seis dentes (6D) e oito dentes (8D).

Acabamento: 1 - carcaças das classes ausente e escassa (0 a $3 \mathrm{~mm}$ ); 3 - carcaças da classe mediana (3 a 6 mm); 6 carcaças das classe uniforme e excessivas (mais de $6 \mathrm{~mm}$ ).

Peso: - Carcaças com peso inferior a 225 kg (<15@);

- Carcaças entre 225 kg e 239,9 kg (15 - 16 @);

- Carcaças entre 240 kg e 254,9 kg (16 - 17@);

- Carcaças entre 255 kg e 269,9 kg (17 - 18@);

- Carcaças entre 270 kg e 284,9 kg (18 - 19@);

- Carcaças entre 285 kg e 299,9 kg (19 - 20@);

- Carcaças entre 300 kg e 314,9 kg (20 - 21@);

- Carcaças entre 315 kg e 329,9 kg (21 - 22@);

- Carcaças acima de 329,9 kg (> 22@). 


\section{RESULTADOS E DISCUSSÃO}

\subsection{Caracterização regional dos abates}

Os bovinos abatidos pelas quatro unidades do grupo frigorífico originamse em sua maioria, de propriedades rurais localizadas no estado em que as unidades frigoríficas estão instaladas. A negociação com produtores de outros estados varia com a localização da unidade no território nacional (Figura 1).

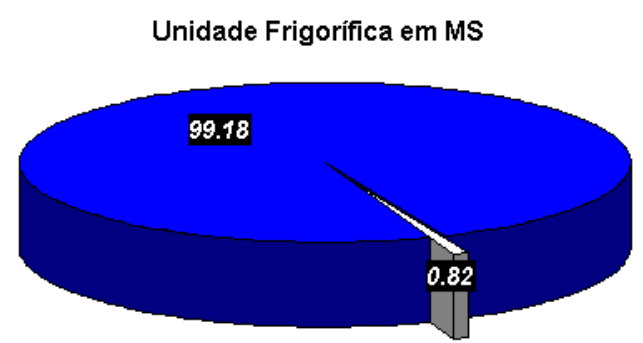

- MS $\triangle M G / G O$

Unidade Frigorifica em Go

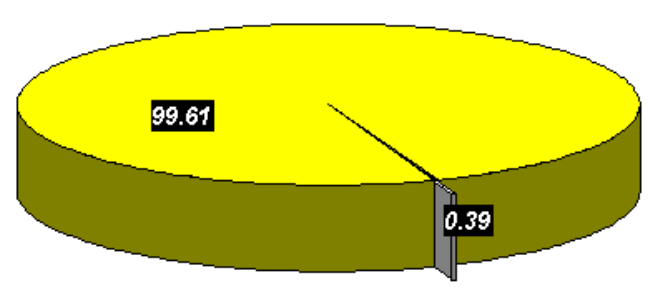

口GO $\square$ MSTO
Unidade Frigorífica em SP

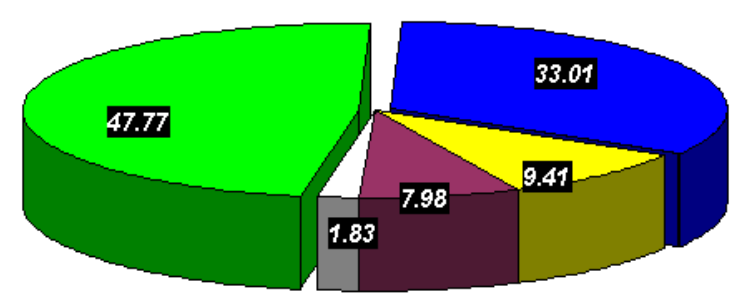

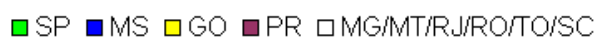

Unidade Frigorífica em MG

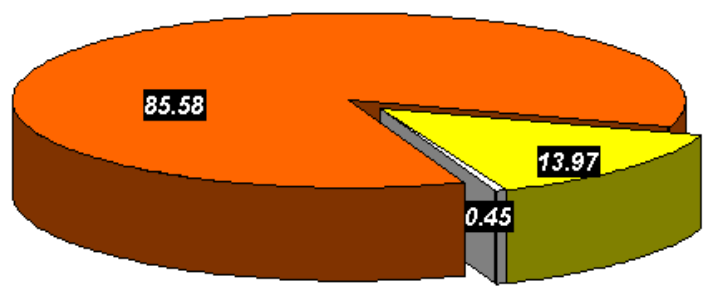

$\square \mathrm{MG} \square \mathrm{GO} \square \mathrm{MSM} M \mathrm{MTR} / \mathrm{SP}$

Figura 1 - llustração gráfica da unidade federativa de origem dos bovinos abatidos conforme a localização da unidade frigorífica 
A unidade de SP foi a que mais recebeu animais de outros estados, com propriedades do MS fornecendo $1 / 3$ dos animais abatidos, sendo também a única unidade que abateu volume representativo de bovinos da região sul, quase $8 \%$ dos abates no período estudado. A localização da unidade em MG ainda favoreceu a aquisição de animais de outros estados, especialmente negociados em GO. Por sua vez, as unidades de MS e GO fizeram aquisições esporádicas fora de suas divisas, quase $100 \%$ originaram-se no próprio estado.

Os maiores volumes de animais adquiridos ocorreram na mesma microrregião das unidades industriais. Em MS, o sudoeste do estado, composto pelas microrregiões de Iguatemi, Dourados e Bodoquena forneceram 86\% dos animais abatidos (Tabela 2).

Tabela 2. Origem geográfica dos bovinos abatidos na unidade frigorífica de MS

\begin{tabular}{cccc}
\hline Ordem & Localidade & Microrregião & Macrorregião \\
\hline $1^{\circ}$ & Itaquiraí & Iguatemi & Sudoeste de MS \\
$2^{\circ}$ & Naviraí & Iguatemi & Sudoeste de MS \\
$3^{\circ}$ & Bela Vista & Bodoquena & Sudoeste de MS \\
$4^{\circ}$ & Jateí & Iguatemi & Sudoeste de MS \\
$5^{\circ}$ & Maracaju & Dourados & Sudoeste de MS \\
$6^{\circ}$ & Amambaí & Dourados & Sudoeste de MS \\
$7^{\circ}$ & Caarapó & Dourados & Sudoeste de MS \\
$8^{\circ}$ & Ponta Porã & Dourados & Sudoeste de MS \\
$9^{\circ}$ & Iguatemi & Iguatemi & Sudoeste de MS \\
$10^{\circ}$ & Juti & Dourados & Sudoeste de MS \\
$11^{\circ}$ & Tacuru & Iguatemi & Sudoeste de MS \\
$12^{\circ}$ & Guia Lopes da Laguna & Dourados & Sudoeste de MS \\
$13^{\circ}$ & Dourados & Dourados & Sudoeste de MS \\
$14^{\circ}$ & Angélica & Iguatemi & Sudoeste de MS \\
$15^{\circ}$ & Laguna Carapã & Dourados & Sudoeste de MS \\
$16^{\circ}$ & Sidrolândia & Campo Grande & Centro Norte de MS \\
$17^{\circ}$ & Campo Grande & Campo Grande & Centro Norte de MS \\
$18^{\circ}$ & Rio Brilhante & Dourados & Sudoeste de MS \\
$19^{\circ}$ & Antônio João & Dourados & Sudoeste de MS \\
$20^{\circ}$ & Eldorado & Iguatemi & Sudoeste de MS \\
\hline
\end{tabular}


Os municípios do Leste de MS forneceram um volume representativo de animais para abate em SP (Tabela 3). As localidades das microrregiões de Três Lagoas e Paranaíba destacaram-se junto às de origem paulista, mas foi a microrregião de Três Lagoas que mais forneceu bovinos para a unidade de SP, representando 20,7\% dos abates no período. As microrregiões de Andradina, Araçatuba, Birigui, Lins, Marília, Assis e Presidente Prudente abateram juntas $32 \%$ dos animais.

Tabela 3. Origem geográfica dos bovinos abatidos na unidade frigorífica de SP

\begin{tabular}{cccc}
\hline Ordem & Localidade & Microrregião & Macrorregião \\
\hline $1^{\circ}$ & Três Lagoas & Três Lagoas & Leste de MS \\
$2^{\circ}$ & Água Clara & Três Lagoas & Leste de MS \\
$3^{\circ}$ & Guaiçara & Lins & Bauru \\
$4^{\circ}$ & Ribas do Rio Pardo & Três Lagoas & Leste de MS \\
$5^{\circ}$ & Brasilândia & Três Lagoas & Leste de MS \\
$6^{\circ}$ & Inocência & Paranaíba & Leste de MS \\
$7^{\circ}$ & Selvíria & Paranaíba & Leste de MS \\
$8^{\circ}$ & Bataguassu & Nova Andradina & Leste de MS \\
$9^{\circ}$ & Santa Rita do Pardo & Três Lagoas & Leste de MS \\
$10^{\circ}$ & Castilho & Andradina & Araçatuba \\
$11^{\circ}$ & Lins & Lins & Bauru \\
$12^{\circ}$ & Pereira Barreto & Andradina & Araçatuba \\
$13^{\circ}$ & Paranaíba & Paranaíba & Leste de MS \\
$14^{\circ}$ & Corumbaíba & Catalão & Sul Goiano \\
$15^{\circ}$ & Presidente Epitácio & Presidente & Presidente \\
$16^{\circ}$ & Sud Menucci & Prudente & Prudente \\
$17^{\circ}$ & Getulina & Andradina & Araçatuba \\
$18^{\circ}$ & Pompéia & Lins & Bauru \\
$19^{\circ}$ & Platina & Marília & Marília \\
$20^{\circ}$ & Sabino & Assis & Assis \\
\hline & & Lins & Bauru \\
\hline
\end{tabular}


As atividades operacionais da unidade localizada em GO dependeram significativamente de animais do Noroeste Goiano. As microrregiões de São Miguel do Araguaia e Rio Vermelho negociaram 64,1\% e 16,7\% dos animais, respectivamente (Tabela 4). Na seqüência estão o Norte Goiano com propriedades localizadas na microrregião de Porangatu $(6,7 \%)$ e o Centro Goiano, especialmente a microrregião de Ceres (5,3\%).

Tabela 4. Origem geográfica dos bovinos abatidos na unidade frigorífica de GO

\begin{tabular}{|c|c|c|c|}
\hline Ordem & Localidade & Microrregião & Macrorregião \\
\hline $1^{\circ}$ & Nova Crixás & $\begin{array}{l}\text { São Miguel do } \\
\text { Araguaia }\end{array}$ & Noroeste Goiano \\
\hline $2^{\circ}$ & $\begin{array}{l}\text { São Miguel do } \\
\text { Araguaia }\end{array}$ & $\begin{array}{l}\text { São Miguel do } \\
\text { Araguaia }\end{array}$ & Noroeste Goiano \\
\hline $3^{\circ}$ & Mozarlândia & $\begin{array}{l}\text { São Miguel do } \\
\text { Araguaia }\end{array}$ & Noroeste Goiano \\
\hline $4^{\circ}$ & Mundo Novo & $\begin{array}{l}\text { São Miguel do } \\
\text { Araguaia }\end{array}$ & Noroeste Goiano \\
\hline $5^{\circ}$ & Aruanã & Rio Vermelho & Noroeste Goiano \\
\hline $6^{\circ}$ & Novo Planalto & $\begin{array}{l}\text { São Miguel do } \\
\text { Araguaia }\end{array}$ & Noroeste Goiano \\
\hline $7^{\circ}$ & Araguapaz & Rio Vermelho & Noroeste Goiano \\
\hline $8^{\circ}$ & Crixás & $\begin{array}{l}\text { São Miguel do } \\
\text { Araguaia }\end{array}$ & Noroeste Goiano \\
\hline $9^{\circ}$ & Britânia & Rio Vermelho & Noroeste Goiano \\
\hline $10^{\circ}$ & $\begin{array}{c}\text { Montes Claros de } \\
\text { Goiás }\end{array}$ & Aragarças & Noroeste Goiano \\
\hline $11^{\circ}$ & Matrinchã & Rio Vermelho & Noroeste Goiano \\
\hline $12^{\circ}$ & Porangatu & Porangatu & Norte Goiano \\
\hline $13^{\circ}$ & Bonópolis & Porangatu & Norte Goiano \\
\hline $14^{\circ}$ & Itapirapuã & Rio Vermelho & Noroeste Goiano \\
\hline $15^{\circ}$ & Jussara & Rio Vermelho & Noroeste Goiano \\
\hline $16^{\circ}$ & $\begin{array}{c}\text { Santa Tereza de } \\
\text { Goiás }\end{array}$ & Porangatu & Norte Goiano \\
\hline $17^{\circ}$ & Uirapuru & $\begin{array}{l}\text { São Miguel do } \\
\text { Araguaia }\end{array}$ & Noroeste Goiano \\
\hline $18^{\circ}$ & Goianésia & Ceres & Centro Goiano \\
\hline $19^{\circ}$ & Santa Isabel & Ceres & Centro Goiano \\
\hline $20^{\circ}$ & Santa Fé de Goiás & Rio Vermelho & Noroeste Goiano \\
\hline
\end{tabular}


A região do Triângulo Mineiro/Alto Paranaíba (72,7\%) foi a que mais forneceu animais para abate na unidade de MG, destacando-se as microrregiões de Ituiutaba (48,3\%), Uberlândia (9,5\%), Frutal (7,8\%), Patos de Minas (2,9\%) e Uberaba (2\%). Outras macrorregiões de relevância para a unidade mineira são o Sul Goiano, especialmente as microrregiões de Quirinópolis (8,5\%) e Catalão (2,4\%), o Noroeste e o Norte de Minas fornecendo juntas $26 \%$ dos bovinos abatidos (Tabela 5 ).

Tabela 5. Origem geográfica dos bovinos abatidos na unidade frigorífica de MG

\begin{tabular}{cccc}
\hline Ordem & Localidade & Microrregião & Macrorregião \\
\hline $1^{\circ}$ & Santa Vitória & Ituiutaba & Triângulo Mineiro/Alto Paranaíba \\
$2^{\circ}$ & Ituiutaba & Ituiutaba & Triângulo Mineiro/Alto Paranaíba \\
$3^{\circ}$ & Capinópolis & Ituiutaba & Triângulo Mineiro/Alto Paranaíba \\
$4^{\circ}$ & Ipiaçu & Ituiutaba & Triângulo Mineiro/Alto Paranaíba \\
$5^{\circ}$ & Gurinhatã & Ituiutaba & Triângulo Mineiro/Alto Paranaíba \\
$6^{\circ}$ & Canápolis & Uberlândia & Triângulo Mineiro/Alto Paranaíba \\
$7^{\circ}$ & Limeira do Oeste & Frutal & Triângulo Mineiro/Alto Paranaíba \\
$8^{\circ}$ & Patos de Minas & Patos de Minas & Triângulo Mineiro/Alto Paranaíba \\
$9^{\circ}$ & Prata & Uberlândia & Triângulo Mineiro/Alto Paranaíba \\
$10^{\circ}$ & Paranaiguara & Quirinópolis & Sul Goiano \\
$11^{\circ}$ & Paracatu & Paracatu & Noroeste de Minas \\
$12^{\circ}$ & Caçu & Quirinópolis & Sul Goiano \\
$13^{\circ}$ & Campina Verde & Frutal & Triângulo Mineiro/Alto Paranaíba \\
$14^{\circ}$ & Corumbaíba & Catalão & Sul Goiano \\
$15^{\circ}$ & Itarumã & Quirinópolis & Sul Goiano \\
$16^{\circ}$ & Varzelândia & Montes Claros & Norte de Minas \\
$17^{\circ}$ & Carneirinho & Frutal & Triângulo Mineiro/Alto Paranaíba \\
$18^{\circ}$ & Gouvelândia & Quirinópolis & Sul Goiano \\
$19^{\circ}$ & Uberlândia & Uberlândia & Triângulo Mineiro/Alto Paranaíba \\
$20^{\circ}$ & Monte Alegre de Minas & Uberlândia & Triângulo Mineiro/Alto Paranaíba \\
\hline & & &
\end{tabular}


As unidades frigoríficas concentraram a aquisição de animais em regiões próximas à sua localização (Figura 2). Os possíveis fatores que favoreceram esta condição seriam a proximidade dos agentes (produtor/frigorífico), disponibilidade de rede viária, solidez financeira do comprador e especialmente a disponibilidade de animais.

A disposição das unidades frigoríficas em MS, estado onde se localiza o maior rebanho bovino brasileiro com 24.983 .821 de cabeças, SP (6 $6^{\circ}$ rebanho bovino), MG $\left(3^{\circ}\right)$ e $\mathrm{GO}\left(4^{\circ}\right)$ permite articular a estratégia de gestão dentro dos maiores centros produtores. As mesorregiões em que se localizam são tradicionais na exploração pecuária, cerca de $1 / 3$ do rebanho bovino de cada estado estão nessas regiões.

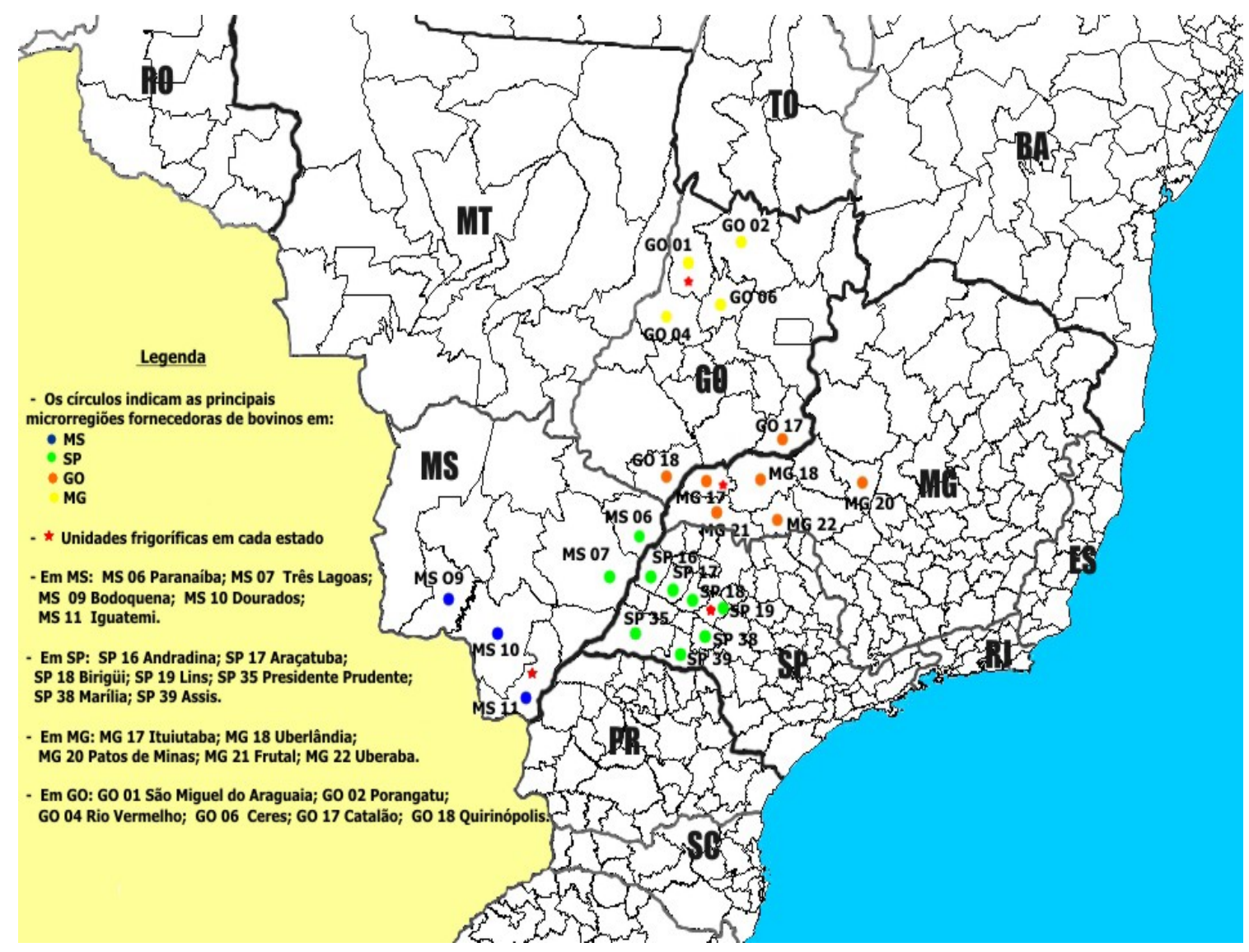

Figura 2 - Microrregiões do Brasil com a localização das unidades frigoríficas e as principais microrregiões fornecedoras de bovinos no período estudado 


\subsection{Características de qualidade da carcaça}

\subsubsection{Classes sexuais}

Em relação ao total de bovinos abatidos no período avaliado, machos inteiros (MI), machos castrados (MC) e fêmeas (F) representaram 10,88\%, $75,96 \%$ e $13,16 \%$, respectivamente. A proporção anual das classes sexuais, nas unidades frigoríficas, apresenta características regionalizadas (Tabela 6).

Tabela 6. Percentagem das classes sexuais em relação ao volume anual de abate em três anos consecutivos de operação, por unidade frigorífica de acordo com sua localização geográfica

\begin{tabular}{ccccccccccc}
\hline $\begin{array}{c}\text { Classes } \\
\text { Sexuais }\end{array}$ & \multicolumn{3}{c}{$\begin{array}{c}\text { Machos } \\
\text { Inteiros }\end{array}$} & \multicolumn{3}{c}{$\begin{array}{c}\text { Machos } \\
\text { Castrados }\end{array}$} & \multicolumn{3}{c}{ Fêmeas } \\
Unidade & & Ano & & \multicolumn{3}{c}{ Ano } & & Ano & \\
Federativa & 2001 & 2002 & $2003^{*}$ & 2001 & 2002 & $2003^{*}$ & 2001 & 2002 & $2003^{*}$ \\
& & $(\%)$ & & & $(\%)$ & & & $(\%)$ & \\
MS & 0,00 & 0,00 & 0,00 & 92,28 & 85,54 & 84,59 & 7,71 & 14,46 & 15,41 \\
SP & 5,79 & 4,02 & 3,33 & 80,03 & 83,07 & 75,19 & 14,17 & 12,91 & 21,48 \\
GO & 38,50 & 34,56 & 35,36 & 56,80 & 54,39 & 43,96 & 4,70 & 11,05 & 20,68 \\
MG & 8,20 & 5,77 & 4,54 & 83,07 & 86,01 & 80,24 & 8,73 & 8,22 & 15,23 \\
\hline
\end{tabular}

${ }^{*}$ Resultados contabilizados até agosto de 2003.

$\mathrm{Na}$ unidade frigorífica localizada em Mato Grosso do Sul não foi registrado o abate de animais inteiros, o que parece indicar possível falha no processo de coleta de dados para esta informação na referida unidade.

Apesar das unidades frigoríficas serem abastecidas principalmente com machos castrados, a unidade localizada em GO apresentou uma boa parcela do abate composta de MI. 
A maioria das propriedades rurais localizadas na região centro-norte do país, de onde provém a maior parte dos bovinos abatidos na unidade de GO, parece dar preferência à produção de bovinos inteiros.

Para os sistemas de produção a vantagem de machos inteiros deve-se à conversão mais eficiente de energia e proteína da dieta em tecido muscular (Bidart et al., 1970), porém alguns produtores castram os animais para reduzir comportamentos indesejáveis (Hinch et al., 1982). Para a indústria o maior rendimento de cortes magros de $\mathrm{Ml}$ é vantajoso, mas em contrapartida a maior proporção do dianteiro e a redução na quantidade de gordura da carcaça destes animais (Field, 1971; Salek, 1998; Seideman et al., 1982), representam desvantagens no processo de comercialização de alguns cortes.

Quanto ao volume de fêmeas abatidas pelo grupo no período estudado, nota-se proporções similares entre as unidades: SP (15,6\%), MS $(13,1 \%)$, GO (12,5\%) e MG (10,5\%). Porém, as freqüências médias anuais diferiram em maior magnitude entre as unidades de SP e MG, com variações anuais de 5 pontos percentuais (pp) equivalente a 59.449 fêmeas abatidas a mais na indústria de SP.

A descrição temporal pormenorizada por unidade frigorífica demonstra que mensalmente as unidades apresentaram uma progressiva participação desta classe sexual no volume mensal de abate, com destaque para as unidades de GO e SP (Figura 3). O crescente abate de fêmeas coincide com a elevação dos abates desta categoria em nível nacional, conforme registros do Instituto Brasileiro de Geografia e Estatística (IBGE, 2005). Porém, a estratégia do grupo parece estar fundamentada na aquisição de machos, já que no mesmo período analisado o abate de fêmeas registrado pelo IBGE nestes estados foi da ordem de $26,6 \%$, enquanto que para o grupo esta classe sexual representou apenas $13,2 \%$ dos abates.

A substituição de machos por fêmeas a partir do segundo semestre de 2002, demonstra a vulnerabilidade da cadeia diante da ciclicidade da atividade. Naquele momento teve início a fase de maior oferta de fêmeas do ciclo 
pecuário, ocorrido pela última vez entre 1995 e 1996, e que se estende ainda em 2005, revelando que o estoque de fêmeas tem-se reduzido nos últimos três anos (dados não apresentados).

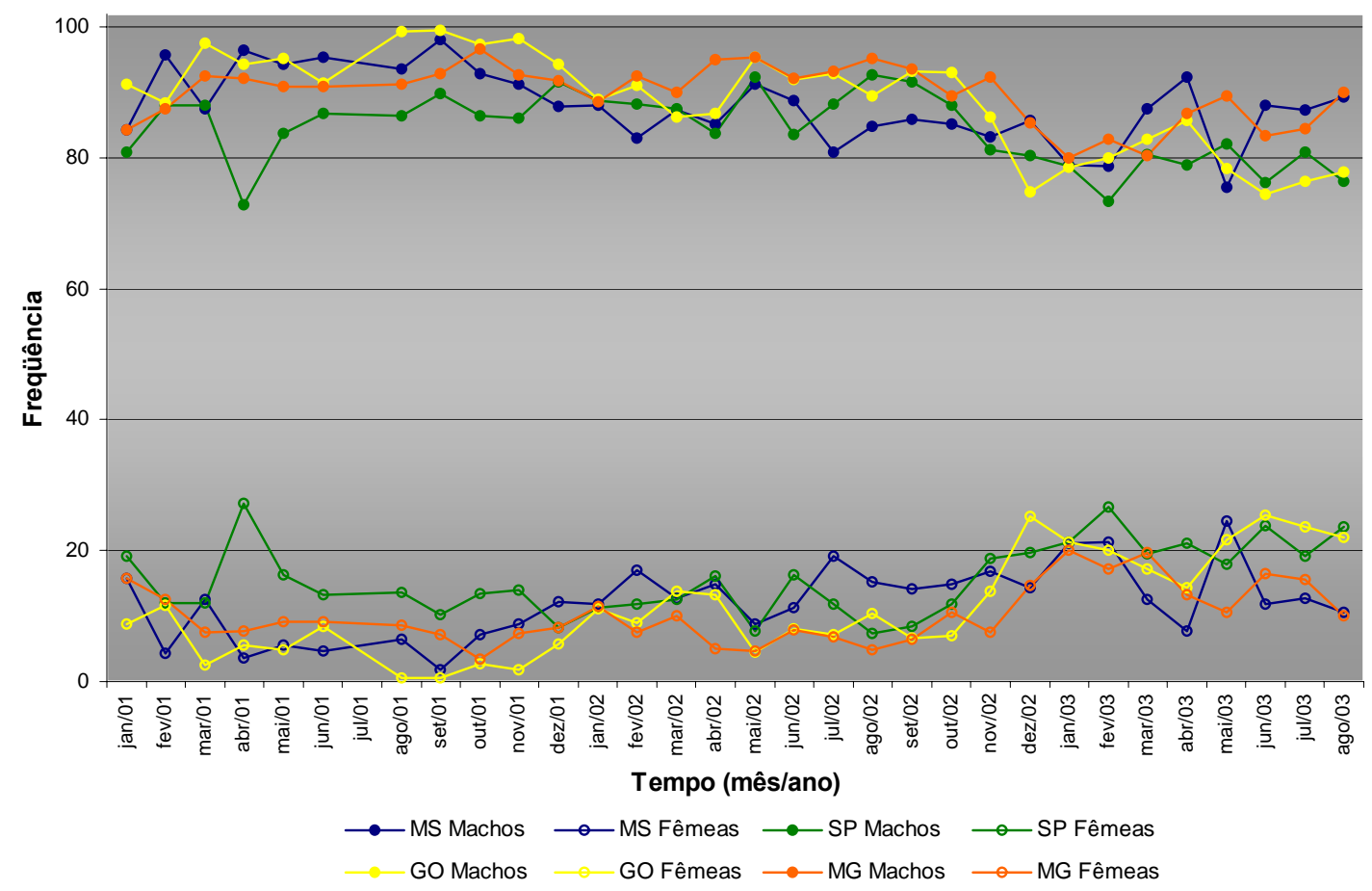

Figura 3 - Evolução temporal da taxa mensal de abate de machos e fêmeas em quatro unidades frigoríficas localizadas nos estados de MS, SP, GO e MG

Este evento é próprio do ciclo plurianual, que corresponde ao período do nascimento de uma bezerra até o momento em que seu primeiro produto macho é abatido, ao considerar os índices médios nacionais os ciclos tendem a ocorrer a cada sete ano (Almeida \& Azevedo, 1996; De Zen, 1998).

Nessas épocas, pela maior oferta de machos para abate e os preços da arroba em queda, reflete negativamente na procura por bezerros. Assim a atividade de cria por hora desestimulada diminui a produção, abatendo um maior número de matrizes e que reduz ainda mais os preços. Quando ocorre a diminuição no volume de fêmeas abatidas, há uma tendência natural de 
recuperação dos preços da arroba do boi. Na tentativa de aumentar sua oferta, cresce a demanda no mercado de reposição, então os criadores passam a reter suas fêmeas dando continuidade ao processo cíclico da pecuária (De Zen, 1998; Haddad, 1999).

Quanto ao ciclo anual da pecuária no país, marcado por um primeiro semestre normalmente de elevada oferta de animais (safra) e um segundo semestre de menor oferta (entressafra), nota-se que nas unidades estudadas houve comportamento diferenciado e próprio para cada região (Figura 4).

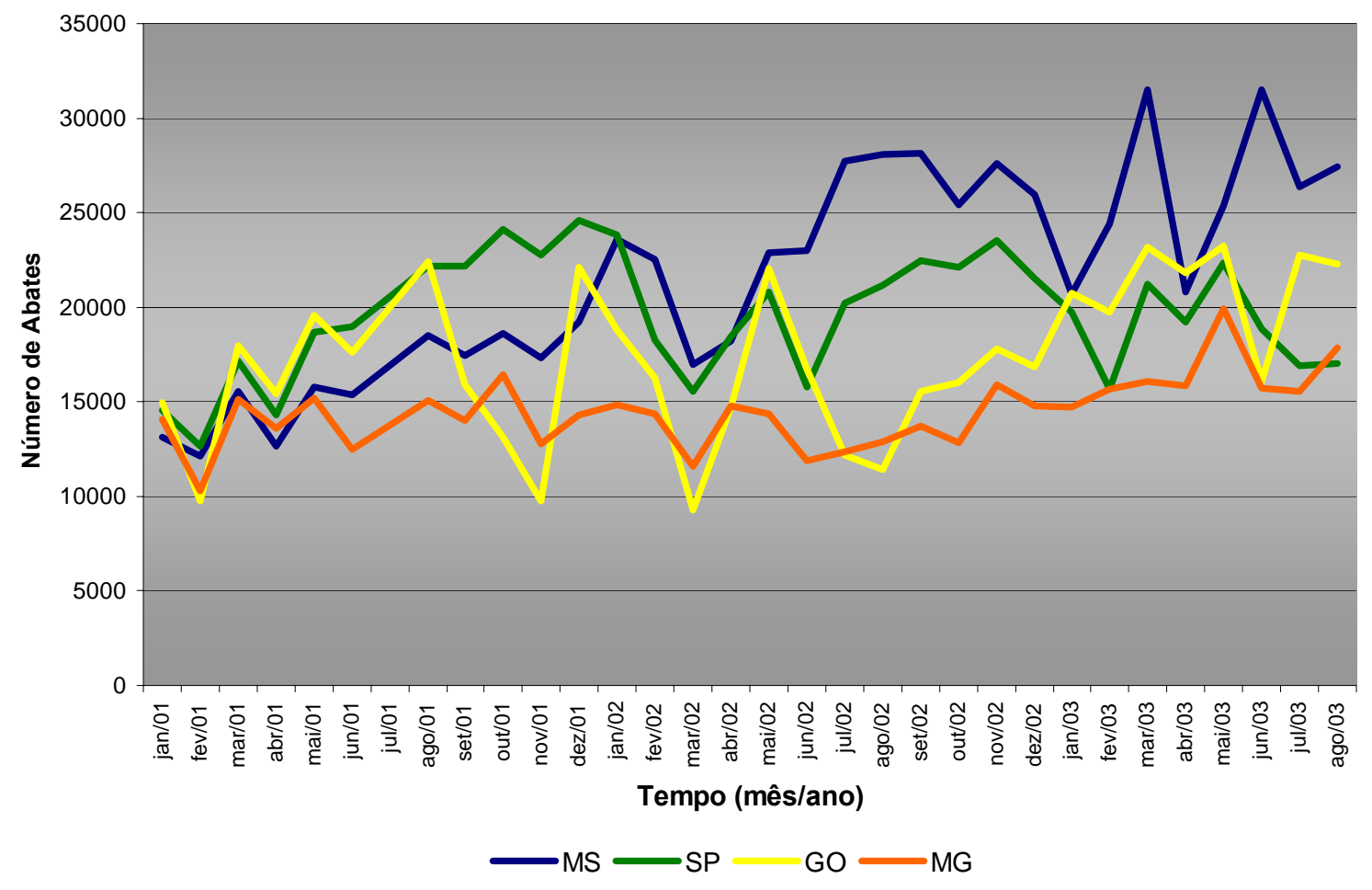

Figura 4 - Evolução temporal do abate mensal de machos em quatro unidades frigoríficas localizadas nos estados de MS, SP, GO e MG

Enquanto no primeiro semestre o número de abate era muito similar entre as unidades, no segundo semestre a disparidade entre as unidades frigoríficas foram nítidas. As unidades que se abastecem em MS e SP elevaram o número de abates no segundo semestre, por sua vez a unidade frigorífica de 
MG manteve o número de abates praticamente constante, mas foi na unidade de GO onde ocorreu maior redução no abate de machos durante a entressafra. Em alguns meses MS superou GO em torno de duas ou três vezes o número de abates, estando a unidade goiana mais susceptível a um desabastecimento no início do segundo semestre.

A sazonalidade produtiva e as peculiaridades regionais tornam complexa a natureza do processo comercialização de bovinos (De Zen, 1999; Maraschin, 2001). Apesar do grupo frigorífico, de uma maneira geral, não sofrer os efeitos da estacionalidade de oferta anual, as variações regionais ao longo do tempo sugerem que as mudanças tecnológicas não têm ocorrido com a mesma velocidade nas diversas regiões geográficas fornecedoras. Isto dificulta um sistema de oferta/aquisição planejada, próprio do tradicional processo de comercialização de bovinos existente no país (Neves et al., 2001), impedindo assim previsões seguras no abastecimento das unidades frigoríficas.

\subsubsection{Idade cronológica}

A determinação da idade pela cronologia dentária permite apenas um cálculo aproximado da idade do animal, além de que numa mesma idade cronológica, raças zebuínas e européias de origem britânica e continental, apresentam diferença na composição corporal por experimentarem diferentes estágios de maturidade fisiológica (Wheeler et al., 1996).

Nos zebuínos o processo de substituição dos incisivos caducos inicia-se aos 28 meses tornando-se dois dentes, aos 35 meses tornam-se quatro dentes, neste momento os animais já atingiram maturidade sexual. Os segundos médios e os cantos são substituídos respectivamente, aos 42 meses (seis dentes) e 52 meses (oito dentes), segundo Camargo \& Chieffi (1971). Esta é uma estimativa, pois este evento pode ser alterado por variações individuais e nutricionais, especialmente de ordem mineral (Moraes, 2001; Tokarnia et al., 1999). 
A análise dos dados referente à idade dos animais revelou que a freqüência de bovinos com quatro dentes foi pequena, sendo nem mesmo sendo encontrada em algumas unidades, ao longo de um ano de atividade. Este fato pode ser indicativo de falhas na determinação e/ou registro da idade dos animais.

A maioria dos bovinos abatidos eram adultos. A freqüência de jovens (J) e adultos (A) para MI e F foi de 30\% e 70\%, e $22 \%$ e $78 \%$, respectivamente. Os resultados temporais desta característica de carcaça são apresentados apenas para MC, uma vez que esta foi a classe sexual predominante em todos os meses e unidades do grupo. Dentre os MC enviados para abate, apenas $17 \%$ eram machos castrados jovens (novilhos).

Nas diferentes unidades os MC apresentaram grupos etários semelhantes, sendo que foi a indústria de MG que mais abateu novilhos, juntamente com a unidade de SP, com oscilações similares, seguidas de MS e GO. Entre os anos houve um aumento no abate de novilhos, especialmente na região de GO (Tabela 7).

Tabela 7. Percentagem de machos castrados com até quatro incisivos permanentes (J) e machos castrados com seis e oito incisivos permanentes $(A)$ em relação ao total de machos castrados abatidos em três anos consecutivos de operação, por unidade frigorífica de acordo com sua localização geográfica

\begin{tabular}{cccccccccc}
\hline U.F. & \multicolumn{2}{c}{ MS } & \multicolumn{3}{c}{ SP } & \multicolumn{3}{c}{ GO } & \multicolumn{3}{c}{ MG } \\
& J & A & J & A & J & A & J & A \\
\hline Ano & \multicolumn{2}{c}{$(\%)$} & \multicolumn{2}{c}{$(\%)$} & & & $(\%)$ & & $(\%)$ \\
2001 & 16,91 & 83,09 & 18,02 & 81,98 & 12,72 & 87,28 & 22,96 & 77,04 \\
2002 & 12,96 & 87,03 & 21,30 & 78,70 & 18,17 & 81,83 & 26,41 & 73,59 \\
$2003^{*}$ & 15,96 & 84,04 & 19,40 & 80,60 & 22,96 & 77,04 & 25,37 & 74,63 \\
\hline
\end{tabular}

* Resultados contabilizados até agosto de 2003 
Em relação ao volume de $\mathrm{MC}$ negociados mensalmente, a série temporal e espacial do abate de novilhos e machos castrados adultos (bois) demonstra que em todas as regiões, existe uma marcante sazonalidade na negociação de animais jovens (Figura 5), caracterizado por dois momentos de maior oferta durante o ano.

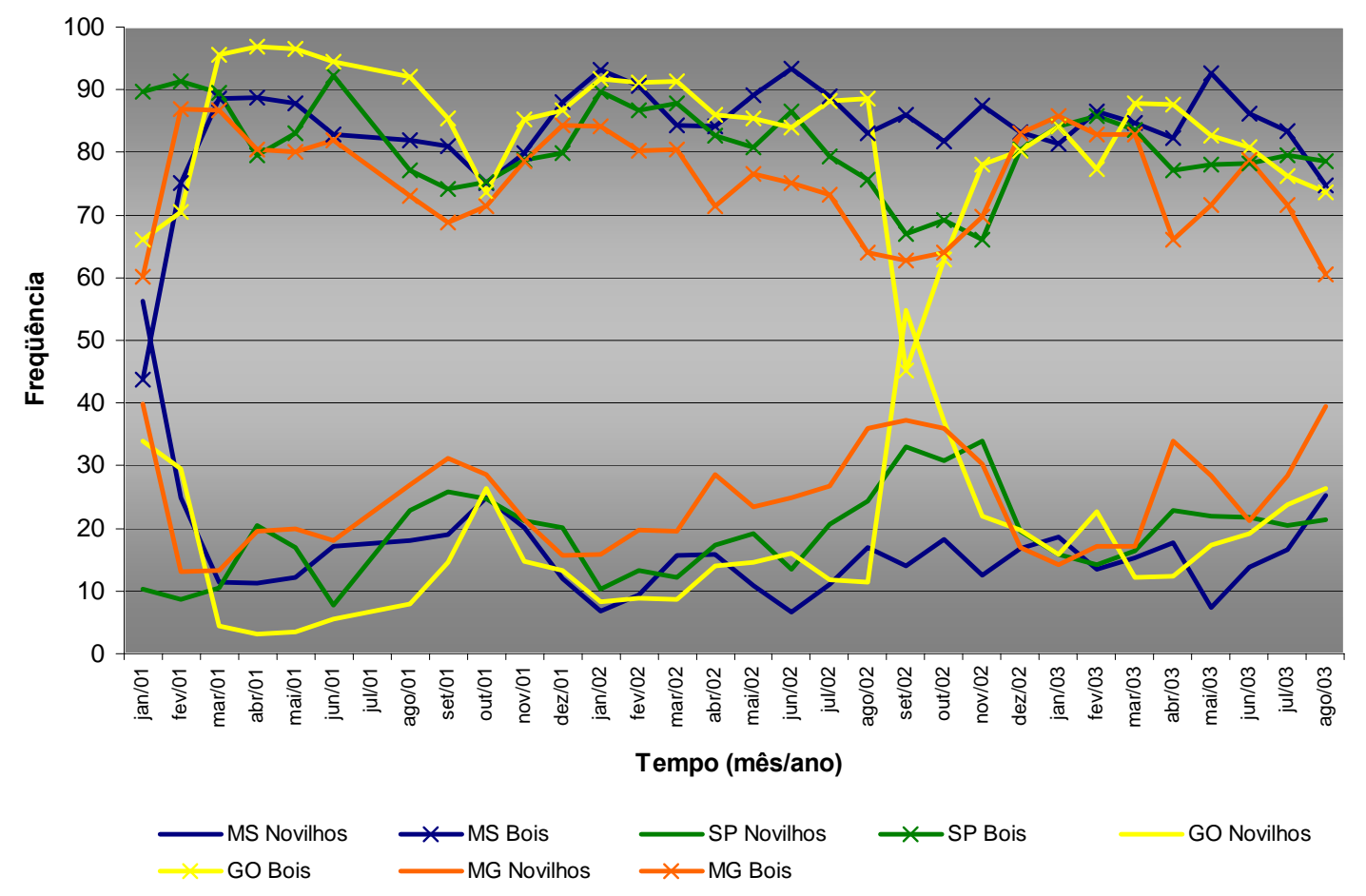

Figura 5 - Evolução temporal da taxa mensal de abate de novilho (até quatro dentes) e boi (seis e oito dentes) em relação ao total de machos castrados abatidos, em quatro unidades frigoríficas localizadas nos estados de MS, SP, GO e MG

No inicio do período de estiagem, entre abril e junho houve uma pequena elevação na oferta, que se reduz durante a seca e volta a aumentar numa proporção e extensão maior, de agosto a novembro, quando torna a diminuir no final do ano. O pico da oferta desta categoria ocorreu normalmente nos meses de setembro e outubro. O único momento em que o abate de novilhos superou 
os animais adultos, foi em setembro de 2002 na unidade de GO, por ocasião do abate de animais de confinamento (Lanna², comunicação pessoal).

Em geral, o abate de novilhos na segunda "safra" estava próximo do dobro verificado no primeiro semestre, com pequeno acréscimo no avançar do período; em cada ano, em torno de 10.000 novilhos foram abatidos a mais nas "safras" do primeiro semestre e de 17.000 nas "safras" do segundo semestre.

A idade de abate é um índice zootécnico de extrema valia aos sistemas produtivos por estar ligado a eficiência econômica das propriedades rurais e a qualidade do produto final (Cezar \& Euclides Filho, 1996; Corrêa et al., 2001).

De maneira geral, as diversas regiões brasileiras que abastecem o grupo têm capacidade de fornecer com facilidade animais condizentes a sistemas de baixa tecnificação, evidenciado pela grande quantidade de MC adultos abatidos. Entretanto, não há indícios de estratégias de gestão com o objetivo de elevar a inserção de animais jovens de modo consistente. No período estudado, isto se evidencia pelo perfil similar de abate nas mesmas épocas do ano.

"A situação atual da bovinocultura de corte no Brasil apresenta similaridade muito grande com a existente no final do século passado e início do século atual" (Haddad, 1999). Embora esta afirmação tenha sido referente à situação do século XIX e XX, continua pertinente ao cenário diagnosticado. Aquele autor expõe os índices zootécnicos brasileiros, publicados pela Empresa Brasileira de Pesquisa Agropecuária (EMBRAPA) em 1978, com idade de abate estimada em 48 meses.

Diante dos resultados deste estudo tem-se que após quase 30 anos, alguns números médios apresentaram pequena evolução. Num cálculo conservador da idade de abate dos MC, considerando animais até quatro dentes (17\% da população) com média de idade de 38,5 meses e aqueles com pelo menos seis dentes (83\%) com média de 47 meses, resulta numa média de 45 meses. Portanto, mesmo em se tratando de algumas das principais regiões

\footnotetext{
${ }^{2}$ LANNA, D.P.D. Laboratório de Nutrição e Crescimento Animal (LNCA). Departamento de Zootecnia, ESALQ/USP. Comunicação pessoal, 2005.
} 
pecuárias do país, a idade de abate manteve-se ao redor dos quatro anos. Estes números sinalizam um ciclo pecuário acima de seis anos.

No entanto, há alguns anos atrás a ocorrência de animais jovens nos currais das indústrias possivelmente não era relevante e freqüente como as médias registradas neste estudo. O pioneirismo de programas estaduais iniciados em MS e expandidos a SP e MG na década de 90 (Almeida et al., 1996; IEL, 2000), bem como as necessidades de intensificação após estabilização da economia em 1994 (De Zen, 1999) catalisaram a difusão de inovações tecnológicas que viabilizam a produção de novilhos. Especialmente nessas regiões pela menor rentabilidade da atividade comparada a outros setores como o sucroalcooleiro e a agricultura, e onde boa parte do custo fixo está mobilizado no valor da terra, devem estar contribuindo para o processo de intensificação e oferta de animais jovens.

Os resultados sugerem um efeito positivo, porém limitado destas práticas com aumento irrisório ao longo dos 31 meses. Nos períodos críticos, pelas condições desfavoráveis ao crescimento e/ou disponibilidade das pastagens, houve a oferta de animais jovens, especialmente a partir de julho até os meses de setembro, outubro ou novembro, que coincide com o momento de oferta dos animais de confinamentos.

Ações eficientes de transferência de tecnologia e informação ainda se fazem necessárias para que o conhecimento gerado em âmbito institucional atinja a classe produtora e mantenha a sustentabilidade da produção orientada pelas exigências mercadológicas (Cezar, 2000; Corrêa et al., 2001; Euclides Filho, 2004; Kichel et al., 1999). A falta de transparência entre produtor e indústria e a dificuldade de estabelecimento de interesses comuns nos segmentos que formam a cadeia, retardam avanços no processo de comercialização que permitiria atender com eficiência as crescentes demandas dos clientes da carne brasileira (Favaret Filho \& De Paula, 1997; Pineda, 2004). 


\subsubsection{Acabamento}

A seguir são apresentados e discutidos os resultados do grau de acabamento em novilhos, uma vez que esta categoria está associada à produção de carne com capacidade de atender positivamente as expectativas do consumo in natura (Pearson, 1966). Em especial, carcaças com características de "Novilho Precoce" - bovinos machos castrados jovens com no máximo quatro dentes, preconizados em diversos programas nacionais de qualidade de carne (Almeida et al., 1996; Associação Brasileira dos Criadores de Angus, 2005; IEL, 2000).

A indústria frigorífica brasileira tem como baliza a compra de carcaças com pelo menos $3 \mathrm{~mm}$ de gordura subcutânea, pela cobertura de gordura proteger a superfície muscular durante o processo de resfriamento da carcaça e de conservação da carne (Junqueira \& Alleoni, 1998).

Novilhos com grau de acabamento 3 tiveram reduzida ocorrência na rotina diária do frigorífico. Ao longo dos 31 meses que compõe a base de dados do estudo, estes novilhos representaram apenas $7,9 \%$ do total de bovinos abatidos. Na unidade de SP o total de abates foi de 10,3\%, superando as demais regiões que registraram em MS 9,1\% e MG 8,4\%, sendo que a indústria de GO registrou a menor freqüência de abates desta categoria, com equivalente a apenas 3,0\% do total de animais abatidos.

As diferentes regiões fornecedoras são determinantes no abastecimento de carcaças com padrão de acabamento 3 em novilhos. As unidades de SP e MS responderam respectivamente por $36,1 \%$ e $34,3 \%$ da produção, enquanto a indústria de MG foi responsável por 20,4\% e finalmente GO com 9,1\%.

$\mathrm{Na}$ rotina industrial, a distribuição dos graus de acabamento estiveram mais próximas entre as indústrias de MS e SP (Tabela 8), onde 2/3 dos novilhos foram agrupados no grau 3. Porém as indústrias de $M G$ e GO que se abastecem predominantemente em áreas de menor latitude na região tropical, comparadas a MS e SP foram menos eficientes em incorporar animais de 
melhor acabamento. Nestas regiões a situação foi antagônica, pois em torno de 2/3 dos novilhos apresentaram grau de acabamento 1 . A unidade de SP com $27,5 \%$, foi a que menos abateu novilhos com acabamento inferior a $3 \mathrm{~mm}$, diferença de 5 pp em relação a MS.

Tabela 8. Percentagem dos graus de acabamento de carcaças de novilhos (até quatro dentes) em três anos consecutivos de operação, de janeiro de 2001 a agosto de 2003, por unidade frigorífica de acordo com sua localização geográfica

\begin{tabular}{cccc}
\hline $\begin{array}{c}\text { Unidade } \\
\text { Federativa }\end{array}$ & 1 & Graus de Acabamento* & 6 \\
\hline & $(\%)$ & $(\%)$ & $(\%)$ \\
MS & 32,5 & 66,8 & 0,7 \\
SP & 27,5 & 65,8 & 6,7 \\
GO & 61,3 & 35,9 & 2,8 \\
MG & 58,0 & 40,4 & 1,6 \\
\hline
\end{tabular}

* Agrupadas pela espessura da gordura subcutânea sobre a carcaça. Grau 1: menos de 3 mm de gordura; Grau 3: de 3 a 6 mm; Grau 6: acima 6 mm

Em todas as regiões, carcaças com gordura de cobertura superior a $6 \mathrm{~mm}$ são raras, destaca-se apenas a região de SP com 6,7\%.

Carcaças de novilhos de grau de acabamento 3 tiveram freqüência reduzida e marcada pela mesma sazonalidade de oferta dos animais jovens. $O$ comportamento no tempo foi irregular em todas as regiões, mesmo entre as unidades que mais abatem bovinos neste padrão de carcaça (Figura 6 e Figura 7).

Cada região exibiu uma particularidade específica ao longo do tempo. As indústrias de SP e MG tiveram variação muito semelhante no volume de abate, ao longo do período estudado. A unidade de MS, apesar de estar entre as que mais abatem novilhos nesse padrão de acabamento, se diferenciou das demais 
no primeiro semestre de 2003 sem ocorrer a maior oferta na entrada do período seco, elevando o número de abate apenas em agosto.

A indústria sul-matogrossense no início de 2001 teve elevado abate de novilhos que foi acompanhado de um grande número de carcaças com acabamento entre 3 e $6 \mathrm{~mm}$ de espessura e acima de $6 \mathrm{~mm}$ (dados não apresentados). Estas observações são difíceis de serem interpretadas, pois em nenhum outro momento repetiram-se esses valores, além de que a oferta de animais de confinamento parecia improvável naquela época.

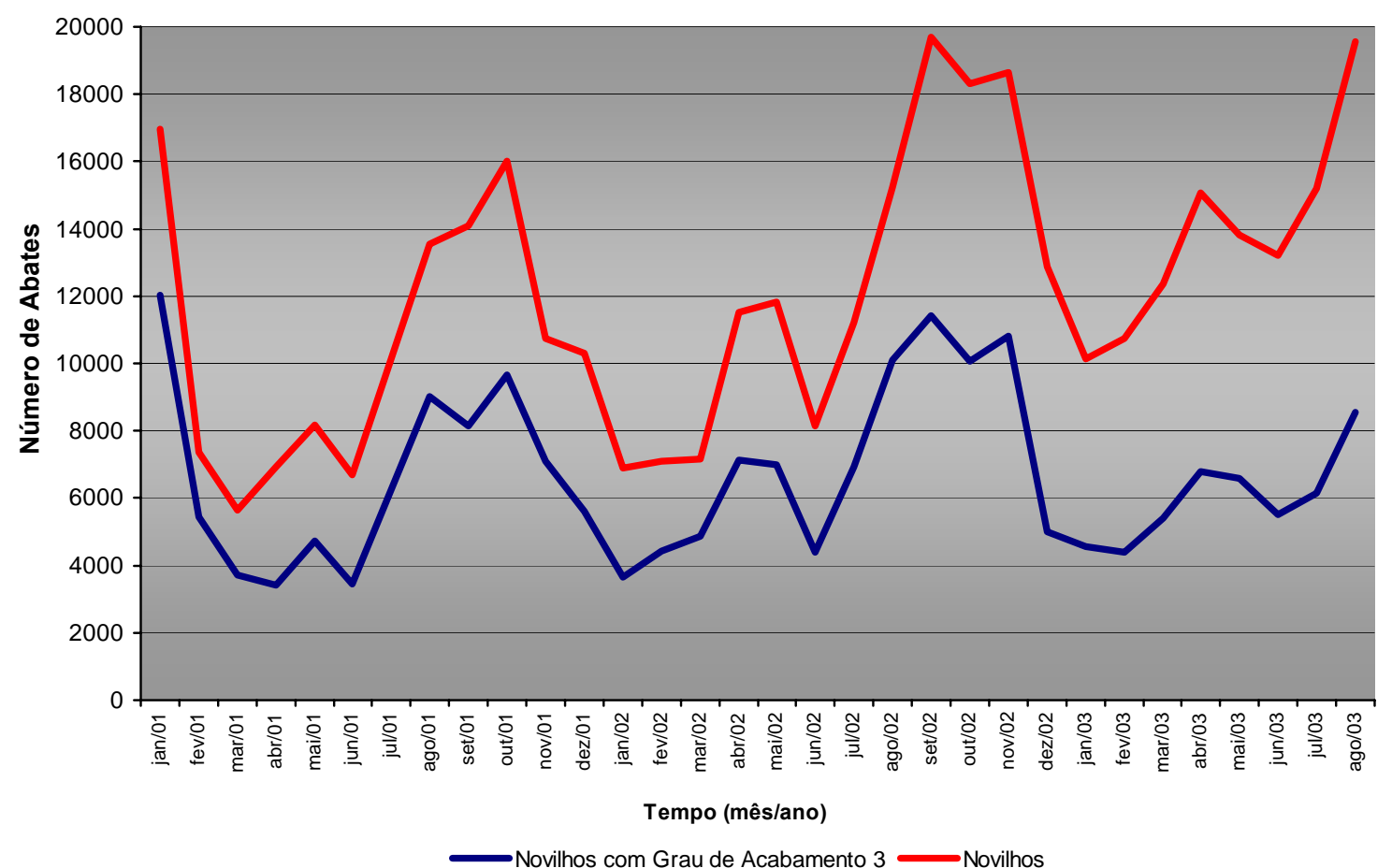

Figura 6 - Evolução temporal do abate mensal de novilhos (até quatro dentes) e novilhos com grau de acabamento $3 \mathrm{em}$ quatro unidades frigoríficas localizadas nos estados de MS, SP, GO, MG 


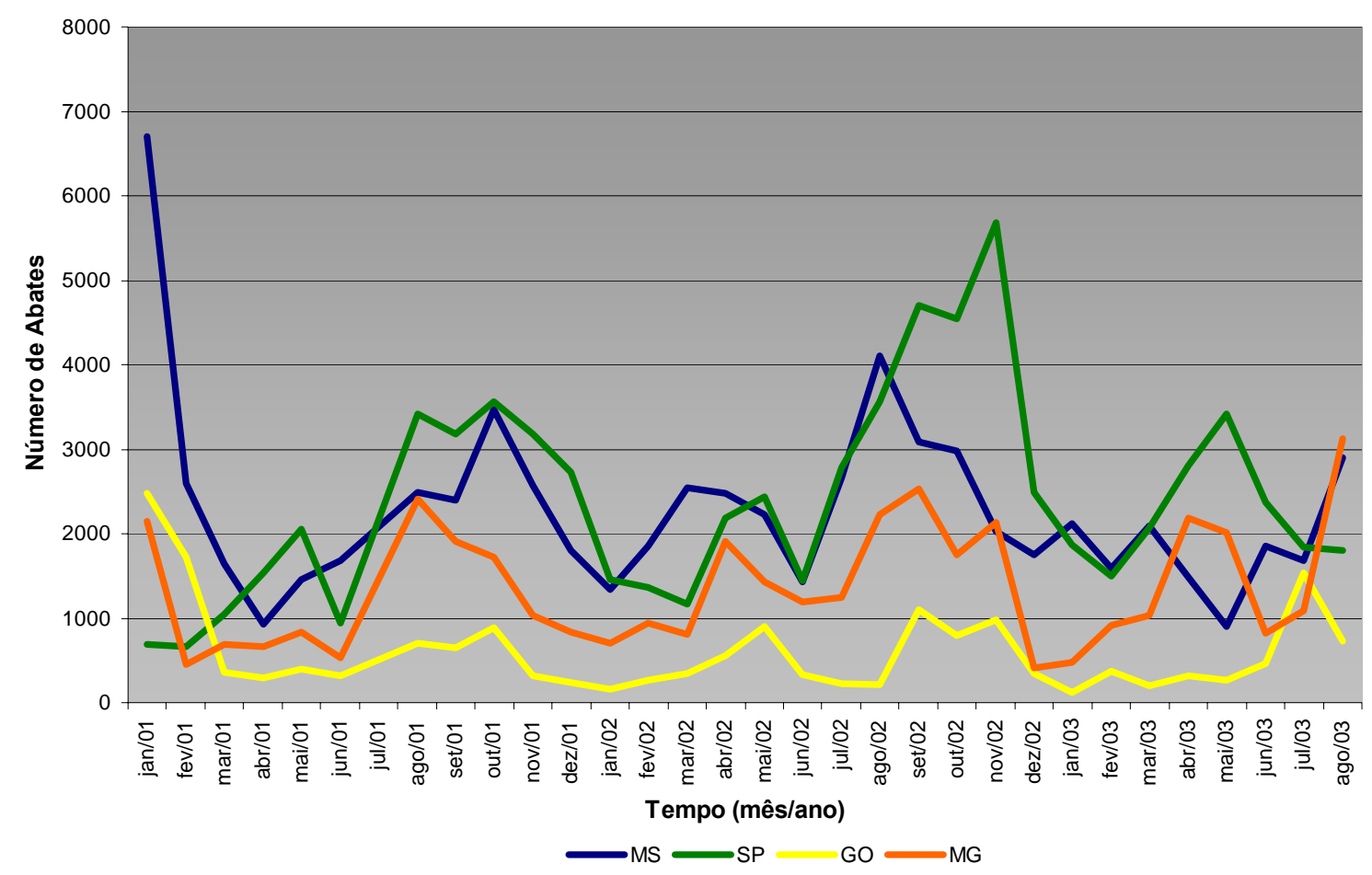

Figura 7 - Evolução temporal do abate mensal de novilhos (até quatro dentes) com grau de acabamento $3 \mathrm{em}$ quatro unidades frigoríficas localizadas em MS, SP, GO e MG

O estado de MS, pelo pioneirismo do "Programa do Novilho Precoce", pode estar experimentando uma renovação de conceitos de produção e influenciando um novo perfil para os produtores, especialmente nas microrregiões de Iguatemi, Dourados e Bodoquena, onde se concentravam 54\% das propriedades inscritas no programa (Almeida et al., 1999), e maiores fornecedores do grupo no estado.

Nas regiões com menor grau de acabamento nos novilhos, GO foi ainda mais problemática que a unidade MG, pois no período estudado esteve sempre abaixo de 1.500 animais/mês, exceto por três dos 31 meses, em janeiro e fevereiro de 2001 e julho de 2003.

O abate de novilhos com espessura de gordura entre 3 e $6 \mathrm{~mm}$ aumentou nos registros do grupo, de maneira lenta e especialmente no período 
de entressafra, como ocorrido para os novilhos. Entretanto, a freqüência de novilhos com acabamento 3 em relação aos novilhos abatidos demonstrou que não houve uma regularidade na oferta de novilhos com acabamento desejável durante o período de estudo (Figura 8).

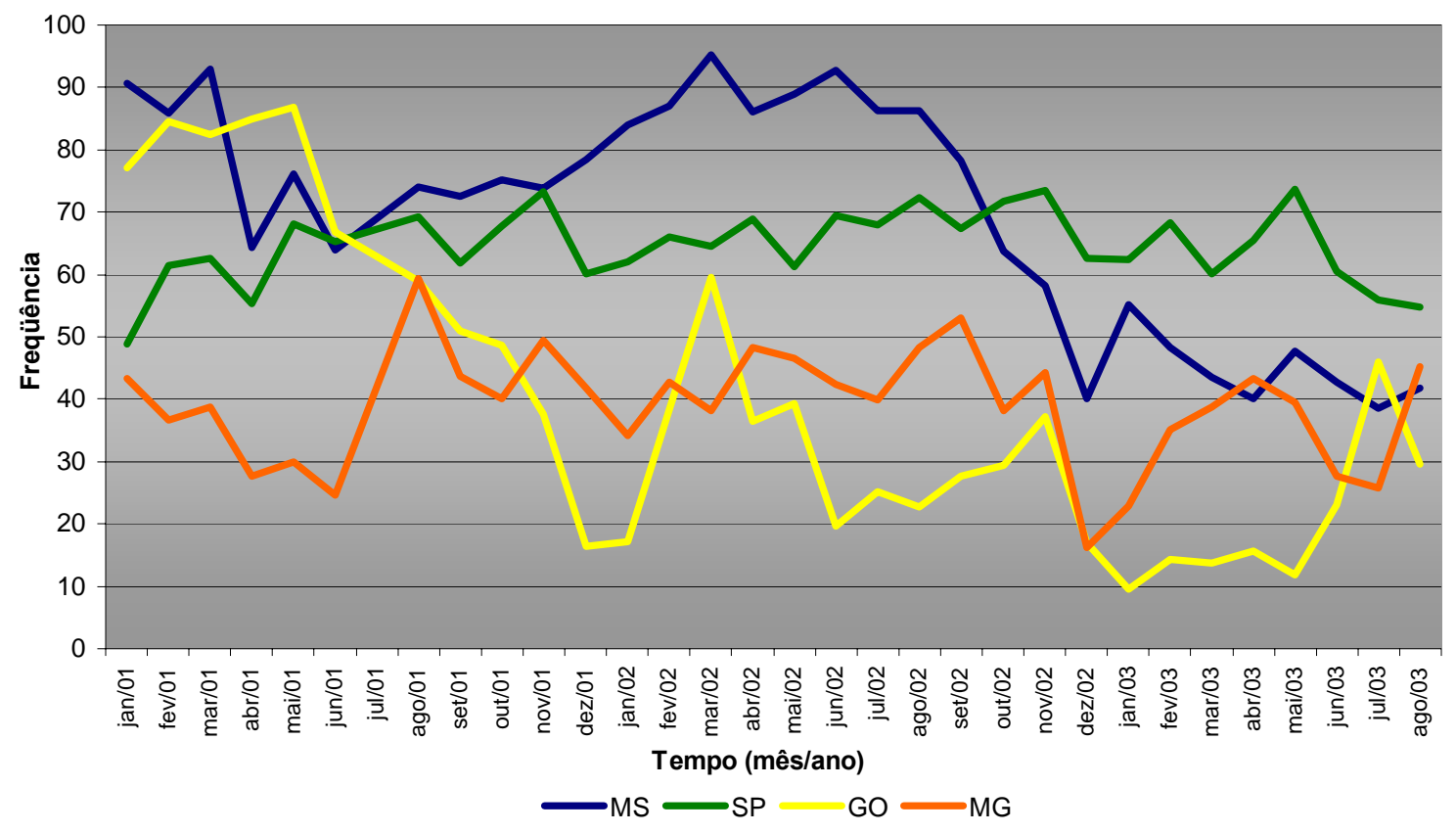

Figura 8 - Evolução temporal da taxa de abate de novilhos (até quatro dentes) com grau de acabamento 3 em relação ao novilhos abatidos em quatro unidades frigoríficas localizadas em MS, SP, GO e MG

A proporção de carcaças com acabamento 3 reduziu-se ao longo do período em todas as regiões onde o grupo atua, exceto na unidade de SP onde a oferta se manteve. De modo geral, ainda que os resultados demonstrem uma ocorrência sazonal similar de novilhos e novilhos com acabamento 3, estes últimos não acompanharam a oferta dos animais jovens na mesma proporção, sobretudo na segunda "safra" do ano onde a diferença foi ainda maior que a observada na primeira "safra" (Figura 6). Em 2002 essa diferença se ampliou, com destaque para o segundo semestre e se agravando ainda mais em 2003.

Uma possível interpretação remete ao componente econômico, que estaria determinando venda antecipada dos animais para abate antes de atingir 
o ponto mínimo de acabamento $(3 \mathrm{~mm})$. No segundo semestre acontece as maiores cotações de preço no ano, historicamente em outubro e novembro há pico do valor pago ao produtor, além de que a cotação da arroba do boi gordo de janeiro de 2001 a agosto de 2003 apresentou tendência de queda, juntamente com aumento no custo de produção pecuária nos estados de atuação do grupo (Centro de Estudos Avançados em Economia Aplicada, 2005).

O modelo estudado é incapaz de assegurar uma atividade industrial frigorífica "caracterizada pelo abate de animais jovens e bem acabados" uma vez que instaladas na região central do país dependem de sistemas de produção conduzidos em pleno ecossistema Cerrados, onde se estima que entre $50 \%$ e $80 \%$ dos quase 50 milhões de hectares de pastagens apresentam algum estádio de degradação (Barcellos, 1996; Vieira \& Kichel, 1995). Portanto, a partir de condições edafo-climáticas tropicais, os segmentos adiante da cadeia, de industrialização e consumo, não podem criar expectativas imediatistas e de grande impacto no perfil da carne produzida no país.

Esta condição pode estar comprometendo a maciez da carne bovina, reconhecida como a qualidade organoléptica mais desejada e valorizada comercialmente pelos consumidores de carne. Todavia, manter este atributo em valores mínimos que garantam satisfação do consumidor e de maneira consistente transformou-se em obstáculo desafiador à cadeia da carne bovina de diversos países (Egan et al., 2001; Koohmaraie, 1996; Ressureccion, 2003; Rhee et al., 2004).

Dentre os critérios mínimos para produção de carne consistentemente macia, a idade de abate e gordura de cobertura são fatores fundamentais ao processo (Shorthose \& Harris, 1990; Tatum et al., 1982).

Entre as recomendações para se reduzir a variação da maciez, estaria a limitação da idade de abate em 30 meses (Koohmaraie et al., 2003). Quanto a idade de abate, o predomínio de animais adultos compromete sistematicamente a qualidade da carne produzida. À medida que os animais envelhecem ocorre 
amadurecimento do tecido conjuntivo, tornando-se termoestáveis pelo maior numero de ligações intercruzadas na molécula de colágeno, condição que favorece a produção de carne dura (Goll et al., 1964; Robins et al., 1973).

A gordura de cobertura não tem relação direta com a palatabilidade, entretanto sua presença reduz o fenômeno de "cold-shortening" que diminui a maciez da carne, para tanto a quantidade mínima de gordura subcutânea seria de pelo menos 5 mm (May et al., 1992; Tatum et al., 1982; Taylor, 2003).

Porém, os resultados de Kuypers (2000) indicam que carcaças de Bos indicus de até 24 meses com gordura de cobertura de $1 \mathrm{~mm}(\mathrm{DP} \pm 0,2)$ e $6 \mathrm{~mm}$ $(\mathrm{DP} \pm 2,1)$ não sofreram "cold shortening", quando submetidas a eletroestimulação de alta voltagem, resultando em carnes mais macias no dia 1 e 14 após o abate.

No país, a escassa produção de animais jovens e com pouca gordura de cobertura na carcaça pode ser revertida, uma vez que o país possui domínio científico e tecnológico (Balsalobre et al., 2002; Corsi, 1994; Kichel et al.,1999; Vilela et al., 2004) para alcançar estes requerimentos zootécnicos em sistemas tropicais e evidentemente conjugá-los a procedimentos industriais pós abate, preservando a qualidade mínima atingida no campo.

As duas ondas de maior oferta de novilhos com acabamento entre 3 e 6 $\mathrm{mm}$ reforçam essa proposta. A primeira safra coincide com o início da redução na disponibilidade e qualidade das pastagens (Euclides et al., 1996; Rosa, 2001), sinalizando para algum tipo de intensificação e/ou retenção dos novilhos para atingirem peso e grau de acabamento para venda; e o segundo momento de maior oferta é compatível com a proposta de maior nível de tecnificação, em especial o confinamento e/ou associados à exploração do crescimento compensatório após período de estresse nutricional durante o período de seca (Boin \& Tedeschi, 1996; Sainz, 2004).

Um elemento "complicador" seria a base zebuína do rebanho bovino nacional, pela sua predisposição genética em produzir carne menos macia (Whipple et al, 1990). Esta condição associada à categoria predominante, 
bovino maduro com pelo menos seis incisivos permanentes (mais de 3,5 anos), compromete a maciez da carne bovina brasileira. A incorporação de fêmeas de descarte ou mesmo matrizes em idade reprodutiva na rotina de abate, por ocasião de ciclo plurianual, contribuem para a produção de carne dura.

No entanto, a idade não é característica limitante no processo industrial brasileiro. A necessidade de manter sua plena atividade, no intuito de mitigar os elevados custos operacionais aliado às limitações dos sistemas de produção, faz com que o processo dependa de animais de idade avançada. Caso contrário, o que seria abatido? A demanda dos consumidores, em especial a estrangeira, requisitando carne de animais comprovadamente jovens, pode surpreender o país (se é que isto já não ocorreu). Neste caso, em quanto tempo o grupo seria capaz de atender tal demanda? Os novilhos teriam gordura mínima no cortes requeridos? Quantos contratos poderiam ser atendidos? Com que freqüência? É um ponto a ser considerado na estratégia financeira e de marketing do grupo, e possivelmente para as demais indústrias brasileiras, já que carcaças com padrões mínimos relacionados à qualidade de carne ocorrem em escala reduzida e sazonal. Situação mais desafiadora ocorreria com contratos de novilhos de até dois dentes.

\subsubsection{Peso da Carcaça}

Nesta seção são expostos os resultados para MC pela relevância no volume de carcaças produzidas, $83 \%$ dos abates do grupo provém destes animais; e para os novilhos com grau de acabamento 3 pela vinculação deste padrão ao conceito de qualidade de carne, para esta categoria foram agrupados os pesos de carcaças acima de 18@.

No período analisado os MC jovens e adultos tiveram diferente distribuição entre as classes de peso (Figura 9). O peso de carcaça se eleva à medida que o animal atinge a maturidade fisiológica, especialmente pelo desenvolvimento do tecido muscular e adiposo (Owens et al., 1995). Sendo 
assim, os animais adultos apresentaram maior freqüência de carcaças com peso elevado, com 40,6\% destas carcaças superiores a 18@, enquanto os novilhos com menor peso de abate registraram apenas 22,9\% nesta mesma faixa de peso.

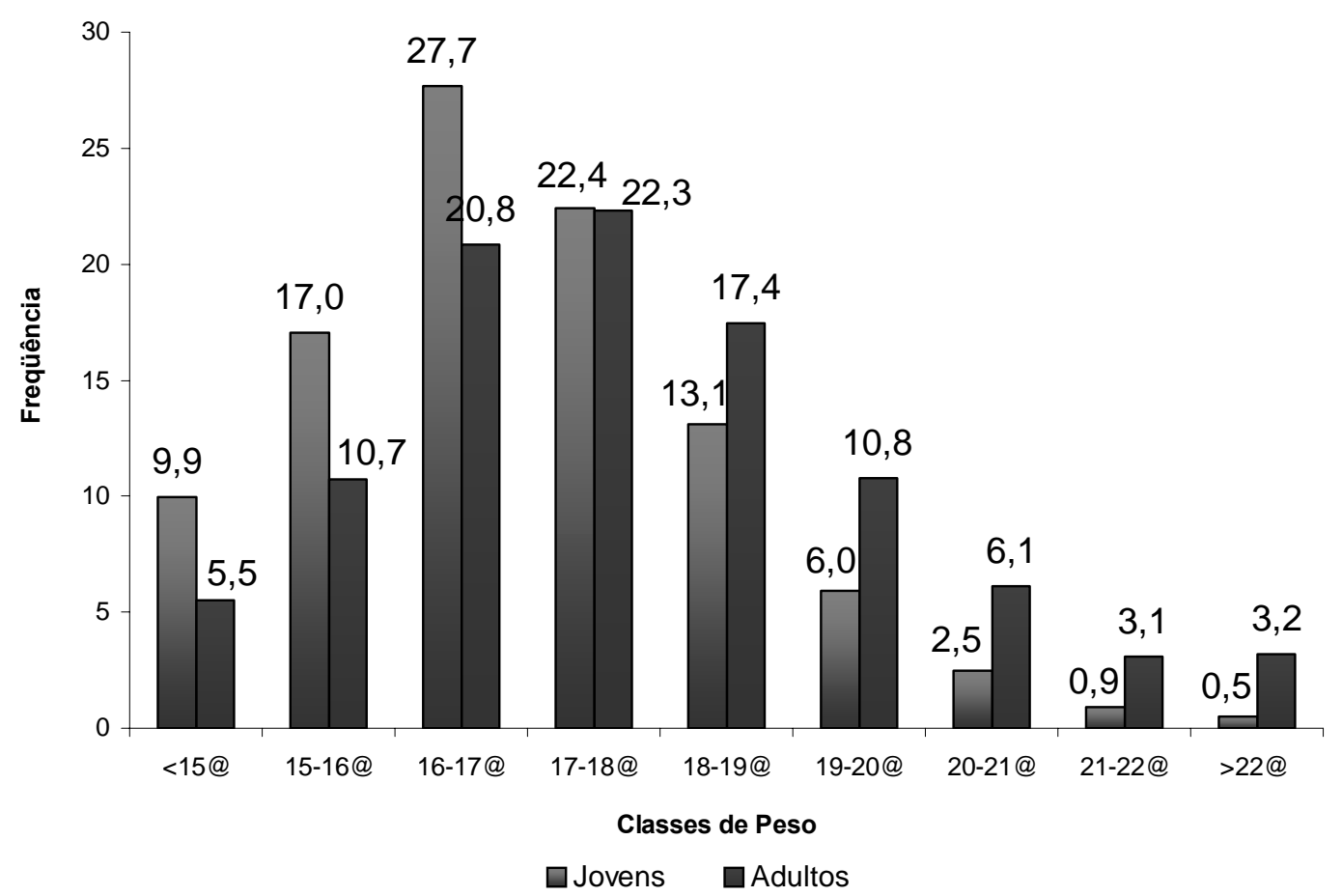

Figura 9 - Distribuição das classes de peso para machos castrados jovens (até quatro dentes) e adultos (seis e oito dentes) em quatro unidades frigoríficas localizadas nos estados de MS, SP, GO, MG de janeiro de 2001 a agosto de 2003

O peso do animal vivo ou da carcaça bovina relaciona-se com a eficiência produtiva e econômica dos sistemas de produção (Cezar \& Euclides Filho, 1996; Corrêa et al., 2001), pois o processo de comercialização brasileiro determina o valor pago ao produtor através do rendimento das carcaças obtidas (peso da carcaça em relação ao peso do animal vivo). Num estudo conduzido junto a produtores no estado de MS, Michels et al. (2000) verificaram que para $30 \%$ dos entrevistados o momento de negociação é determinado pelo limite de 
peso de seus animais, enquanto $60 \%$ dos produtores negociavam por necessidade financeira ou oportunidade de preço.

O peso que se pratica no momento da comercialização é definido pela indústria, para os machos o peso de carcaça deve estar entre 240 e $270 \mathrm{~kg}$ (16 a 18@) como afirma Picchi (2000). Os resultados indicam que em torno de $46,6 \%$ das carcaças de machos castrados encontravam-se nessa faixa de peso, enquanto 21,6\% pesavam menos 16@, ou seja, pelo menos 1/5 dos animais negociados estavam aquém do peso normalmente requerido, o que sugere uma eventual necessidade de acelerar o giro de capital por parte do produtor ao entregar animais mais leves; e cerca de $1 / 3(31,8 \%)$ foram negociados acima de 18@.

Em relação à idade de abate, $43,1 \%$ dos machos castrados adultos e $50,1 \%$ dos machos castrados jovens atingiram a faixa de peso requerida pela indústria. Já a classe de peso predominante para os animais adultos foi de 17 a 18@, registrando $22,3 \%$ dos abates, similar a freqüência de novilhos abatidos nesta classe de peso, 22,4\%. Entretanto, os novilhos predominaram com carcaças na classe de peso de 16 a $17 @$, com 27,7\% dos abates.

Em referência a dados americanos, o peso médio de carcaça de animais confinados está em 345kg (DP $\pm 15,2 \mathrm{~kg}$ ) (Felicio, 1994). No sistema estudado, o peso médio das carcaças de MC foi de 264,4kg (DP $\pm 15,2 \mathrm{~kg}$ ), equivalente a 17,6@, valor acima da média nacional de 200kg (Zimmer \& Euclides Filho, 1997) e similar ao peso médio de $268 \mathrm{~kg}(17,8 @)$ ao encontrado em uma unidade frigorífica na cidade de Barretos, no estado de São Paulo (Pardi et al., 2001).

A associação do peso da carcaça à maturidade e acabamento da carcaça visa acrescentar rentabilidade ao processo de qualidade, ou seja, um produto com especificações conhecidas depende também de um adequado rendimento de cortes na desossa. Os frigoríficos exportadores buscam carcaças de peso homogêneo e gordura de cobertura entre 3 e $6 \mathrm{~mm}$, pois carcaças padronizadas garantiriam maior eficiência industrial (quilogramas de 
carcaça/homem/hora), programação de abate pelo perfil do lote, agregação de valor e estratégias de comercialização da carne (Pedroso, 2000; Crespo \& Andrade, 1998).

No estudo conduzido, pelo menos metade $(53,2 \%)$ dos novilhos com grau de acabamento 3 produziram carcaças entre 16 e 18@, a maior freqüência ocorreu na região de MS (56,2\%), seguida de SP $(53,4 \%)$, GO $(53,1 \%)$ e MG $(48,2 \%)$. A unidade frigorífica de MG apesar de abater menos da metade dos animais na referida faixa de peso, foi a que mais abateu novilhos precoces com maior peso de carcaça (Figura 10).

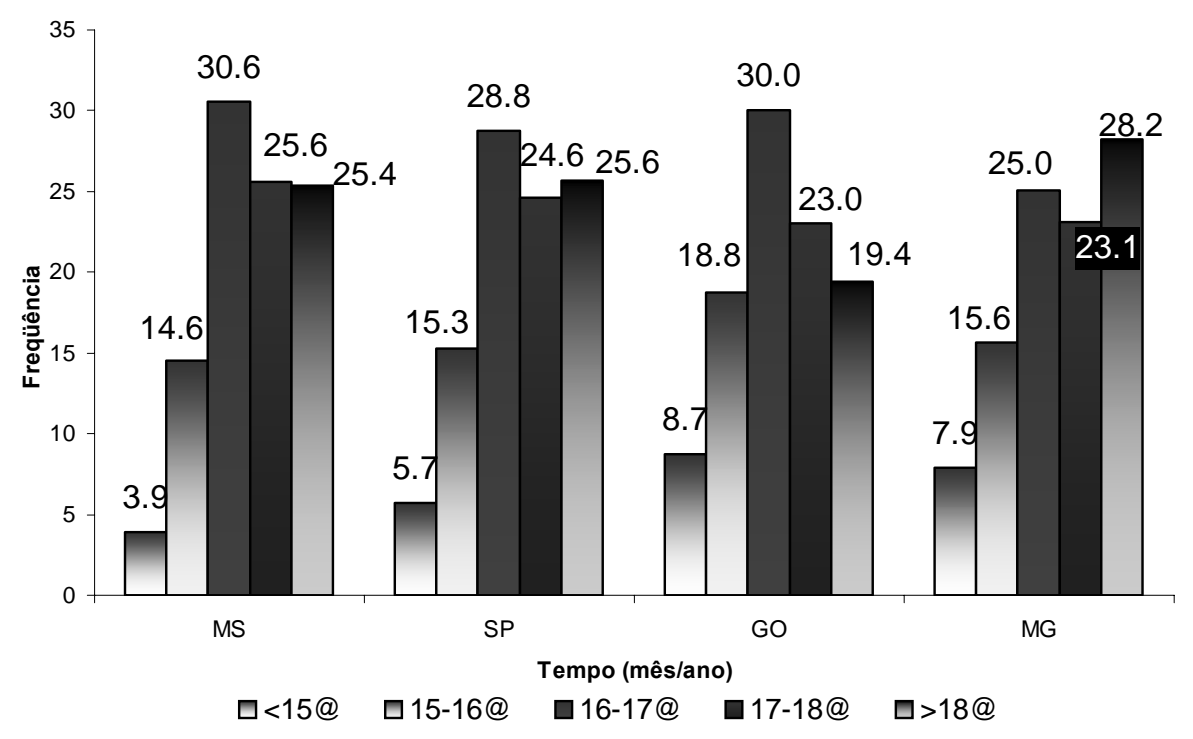

Figura 10 - Distribuição das classes de peso das carcaças de novilhos com acabamento 3. Dados coletados entre janeiro de 2001 a agosto de 2003 em quatro unidades frigoríficas localizadas em MS, SP, GO, MG

O predomínio de MC mais velhos e com peso de abate elevado, média de 268 kg ou 17,8@, evidenciam que as atividades industriais do grupo não se baseiam prioritariamente no setor de produção de carne bovina para consumo in natura. Carcaças mais pesadas diluem o custo operacional pela quantidade de carne aproveitável, contudo a maior vantagem no abate de animais pesados 
e adultos está na magnitude do tamanho corporal de indivíduos maduros, permitindo à indústria obter maior quantidade de couro e subprodutos por unidade animal. Os subprodutos representam em torno de $40 \%$ do peso do animal (Figura 11).

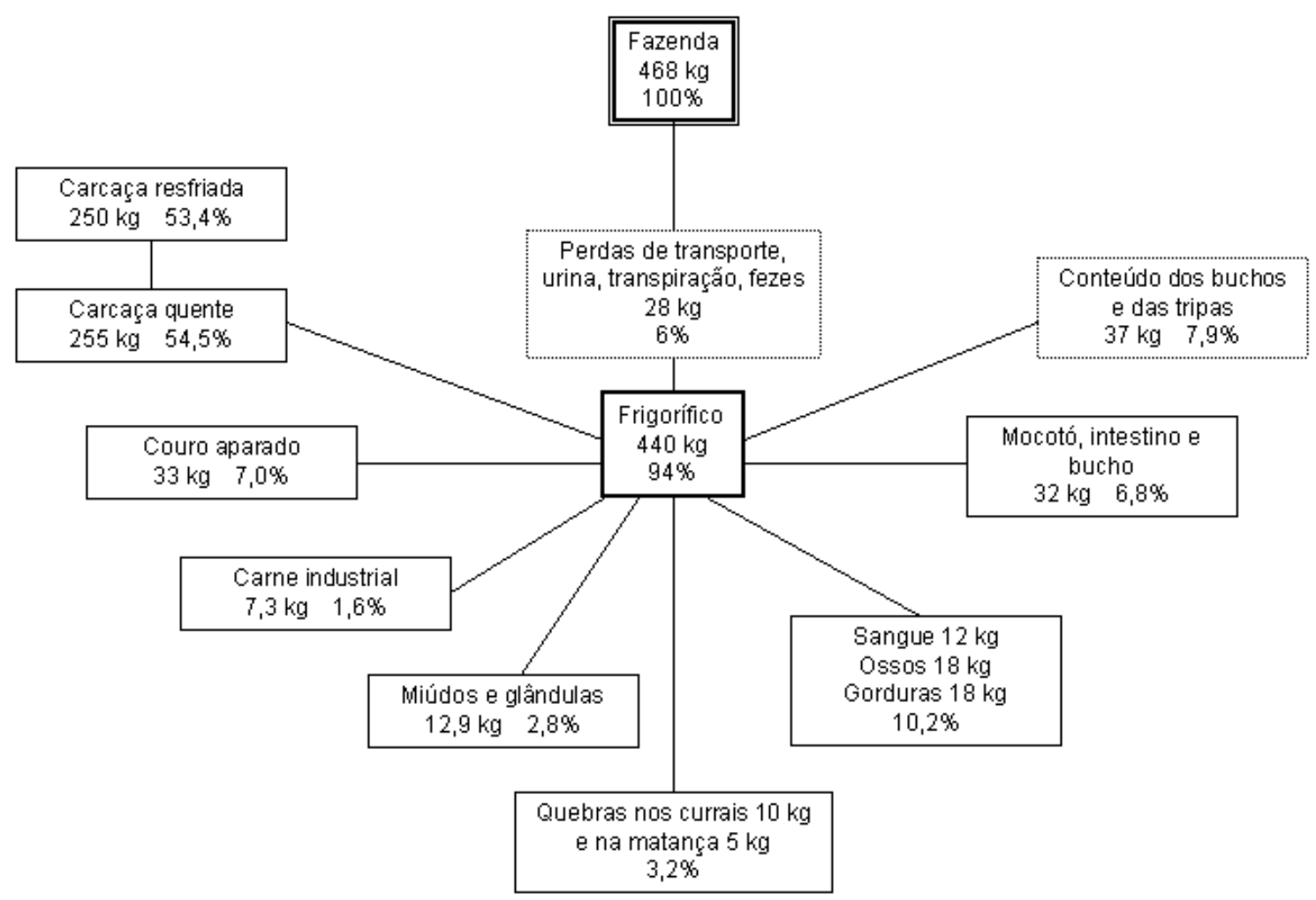

Figura 11 - Desmonte de um bovino. Fonte: Pedro de Felício e Vasco Picchi. In: Alimandro et al., 2001. Agenda para a Competitividade do Agribusiness Brasileiro

A diversificação do processo industrial pela oferta de subprodutos comestíveis, a fabricação de produtos de higiene e limpeza a partir de sebos, aparas de gordura e outros subprodutos, a produção de carne industrializada (IEL, 2000; Souza \& Montenegro, 2000), e o beneficiamento do couro (e.g. couro semi-acabado e acabado, produção de sapatos) (Frizzo Filho, 2003; Santos et al., 2002) permite a indústria frigorífica agregar valor em cada bovino 
abatido e assim ampliar seu poder de negociação a partir de cada animal abatido e não depender exclusivamente dos clientes de carne bovina.

A desorganização da cadeia e limitada troca de informações têm permitido a apropriação intensa e contínua de benefícios por um dos segmentos da cadeia, assim a ausência de planejamentos sistêmicos que atinjam os integrantes da cadeia de carne faz da carne bovina um alimento sem especificação, diferenciação ou mesmo diversificação de suas características, o que torna o processo de produção e o produto carne bovina ineficientes para competir no mercado nacional e internacional (De Zen, 1999; Favaret Filho \& De Paula, 1997).

É possível aumentar a consistência de algumas características da carne bovina e direcioná-la a diversos nichos de consumidores, mas são fundamentais estratégias de ação conjunta entre produtores e indústria (Roland \& Schroeder, 2002). Apesar desta preocupação fazer parte das principais cadeias mundiais de carne bovina, esta reordenação de valores e busca de oportunidades depende dos produtores (Purcell, 2001), estes são capazes de reorganizar seus sistemas para atender a demanda dos consumidores, desde que haja retorno econômico para tais investimentos (Tatum et al., 1999).

Estas informações podem auxiliar na coordenação de ações locais ou regionais junto a fornecedores e com isso aumentar a produção de carcaças com especificações mínimas e/ou explorar a diversidade de carcaças produzidas mês a mês, e na versatilidade encontrada, agregar valor transferindo informações intrínsecas do produto, como sexo, idade e grau de acabamento, aos segmentos posteriores e estes definirem suas preferências, caso o interesse do grupo esteja em atender as expectativas dos clientes de carne. 


\section{CONCLUSÕES}

- A região geográfica das unidades frigoríficas teve influência nas características de carcaça;

- Não ocorreu estacionalidade de oferta para o grupo frigorífico;

- Houve aumento no abate de fêmeas no período;

- Houve predomínio de carcaças provenientes de animais adultos;

- A oferta de novilhos para abate ocorreu em dois picos anuais;

- Houve disparidade na evolução dos abates entre novilhos e novilhos com acabamento mediano;

- As carcaças de novilhos situaram-se em classes inferiores de peso ao abate. 


\section{REFERÊNCIAS BIBLIOGRÁFICAS}

AGUIAR, A.P.A. Manejo de pastagens. Guaíba: Editora Agropecuária, 1998. $139 \mathrm{p}$.

ALIMANDRO, R.; PINAZZA, L.A.; WEDEKIN,I.; NUNES, E.P. et al. Agenda para a competitividade do agribussines brasileiro: base estatística 2001/02. Rio de Janeiro: FGV; São Paulo: ABAG, 2001. 288 p.

ALMEIDA, A.J.; AZEVEDO, C. Semiconfinamento. 2.ed. São Paulo: Globo,1996.184 p.

ALMEIDA, A.J.; BUNGESTAB, D.J.; BUGENSTAB, E.J. O novilho precoce no Mato Grosso do Sul: um moderno sistema de produção de carne. Campo Grande: UFMS, 1996. 170 p.

ALMEIDA, A.J.; BUNGESTAB, D.J.; VASCONCELOS, J.T.; BUGENSTAB, E.J. Novilho precoce: caminho para o sucesso na pecuária. Campo Grande: UFMS, 1999. $196 \mathrm{p}$.

ALLEN, D. Planned beef production and marketing. Oxford: BSP Professional Books, 1990. 232 p.

AMARAL, R. Cadeia produtiva de carne bovina: organizar para competir. Carne bovina: eficiência produtiva e mercado. Informe Agropecuário, v. 21, n. 205, p. 17-22, jul./ago. 2000.

ANDRADE, N.O. Acabamento de bovinos em confinamento. In: COORDENADORIA DE ASSISTÊNCIA TÉCNICA E INTEGRAL. Bovinocultura de corte. Campinas, 1988. p. 57-80. (Impresso Especial).

ASSOCIAÇÃO BRASILEIRA DE CRIADORES DE ANGUS. http://www.angus.org.br/carne/certificada.php (05 jun. 2005)

ASSOCIAÇÃO BRASILEIRA DE INSEMINAÇÃO ARTIFICIAL. http://www.asbia.com.br (20 jul. 2005). 
AZEVEDO, P.F. de. Comercialização de Produtos Agroindustriais. In: BATALHA, M.O. Gestão Agroindustrial. São Paulo: Atlas, 1997. v. 1, cap. 2, p. 49-82.

BALSALOBRE, M.A.A.; SANTOS, S.M.; de BARROS, A.L.M. Inovações tecnológicas, investimentos financeiros e gestão de sistema de produção animal em pastagens. In: SIMPÓSIO SOBRE MANEJO DA PASTAGEM: INOVAÇÕES TECNOLÓGICAS NO MANEJO DE PASTAGENS, 19., Piracicaba, 2002. Anais. Piracicaba: FEALQ, 2002. p. 1-30.

BARBOSA, P.F.; BUENO, R.S. Sistemas mistos de produção de leite e carne bovina. In: SIMPÓSIO SOBRE MANEJO E NUTRIÇÃO DE GADO DE LEITE, Goiânia, 2000. Anais. Goiânia: CBNA, 2000, p. 53-68.

BARCELLOS, A.O. Sistemas extensivos e semi-extensivos de produção pecuária bovina de corte nos Cerrados. In: SIMPÓSIO SOBRE OS CERRADOS, 8., Brasília, 1998. Anais. Planaltina: EMBRAPA CPAC, 1996. p. 130-136.

BERNDT, A.; CRUZ, G.M da; LANNA, D.P.D.; TULLIO, R.R.; ALLEONI, G.F.; CORDEIRO, C.A. Composição física da $9-11^{a}$ costelas de tourinhos de diferentes grupos genéticos em confinamento em relação ao status nutricional na fase de pastejo (compact disc). In: REUNIÃO ANUAL DA SOCIEDADE BRASILEIRA DE ZOOTECNIA, 38., Piracicaba, 2001. Anais. Piracicaba, 2001.

BIDART, J.B.; KOCH, R.M.; ARTHAUD, V.H. Comparative energy use in bulls and steers. Journal of Animal Science, v. 30, p. 1019-1022, 1970.

$\mathrm{BLACH}, \mathrm{R}$. The economics of producing consumer-demanded beef. In: 2003 BEEF PROCEEDINGS 2003. http://www.livestock.congress.com/beef.html (15 ago. 2004)

BOIN, C.B.; TEDESCHI, L.O. Sistemas intensivos de produção de carne bovina: II. Crescimento e acabamento. In: SIMPÓSIO SOBRE PECUÁRIA DE CORTE: PRODUÇÃO DE NOVILHO DE CORTE, 4., Piracicaba, 1996. Anais. Piracicaba: FEALQ, 1996. p. 205-228.

BOLEMAN, S.L.; BOLEMAN, S.J.; MORGAN, W.W.; HALE, D.S.; GRIFFIN, D.B.; SAVELL, J.W.; AMES, R.P.; SMITH, M.T.; TATUM, J.D.; FIELD, T.G.; SMITH, G.C.; GARDER, B.A.; MORGAN, J.B.; NORTHCUTT, S.L.; DOLEZAL, H.G.; GILL, D.R.; RAY, F.K. National Beef Quality Audit - 1995: survey of producer - related defects and carcass quality and quantity attributes. Journal of Animal Science, v. 76, n. 1; p. 96-103, 1998. 
BÜRGI, R.; PAGOTTO, D.S. Aspectos mercadológicos dos sistemas de produção animal em pastagens. In: SIMPÓSIO SOBRE MANEJO DA PASTAGEM: INOVAÇÕES TECNOLÓGICAS NO MANEJO DE

PASTAGENS, 19., Piracicaba, 2002. Anais. Piracicaba: FEALQ, 2002. p. 217-231.

CAMARGO, M.X.; CHIEFFI, A. Ezoognósia. Água Branca: Instituto de Zootecnia, 1971. 320 p.

CENTRO DE ESTUDOS AVANÇADOS EM ECONOMIA AVANÇADA. http://www.cepea.esalq.usp.br (30 maio 2005).

CEZAR, I.M.; EUCLIDES FILHO, K. Novilho precoce: reflexos na eficiência e economicidade do sistema de produção. Campo Grande: Embrapa Gado de Corte, 1996. 31 p.

CEZAR, I.M; COSTA, F.P.; PEREIRA, M.A. Perspectivas de gestão em sistemas de produção animal: desafios a vencer diante de novos paradigmas (compact disc). In: REUNIÃO ANUAL DA SOCIEDADE BRASILEIRA DE ZOOTECNIA, 41., Campo Grande, 2004. Anais. Campo Grande: SBZ, 2004

CEZAR, I.V. Fundamentos de uma nova abordagem de pesquisa e extensão para facilitar o processo de tomadas de decisão do produtor rural. Campo Grande: EMBRAPA Gado de Corte, 2000. 48 p.

CHARLES, D.D.; JOHNSON, E.R. Breed differences in amount and distribution of bovine carcass dissectible fat. Journal of Animal Science, v. 42, n. 2, p. 332-341, 1976.

CORRÊA, E.S.; VIEIRA, A.; COSTA, F.P.; CEZAR, I.M. Sistema intensivo de produção de carne de bovinos nelores no Centro-oeste do Brasil. Campo Grande: Embrapa Gado de Corte, 2001. 49 p.

CORSI, M. Pastagens de alta produtividade. In: PEIXOTO, A.M.; MOURA, J.C. de; FARIA, V.P. de (Ed.). Pastagens: fundamentos da exploração racional, Piracicaba: FEALQ, 1994. p. 477-494.

COSTA, C.; MONTEIRO, A.L.G.; OLIVEIRA, P.S.R.; ALMEIDA JÚNIOR, G.A. Correção do solo e estabelecimento da pastagem In: SIMPÓSIO SOBRE MANEJO DE PASTAGEM: PLANEJAMENTO DE SISTEMAS DE PRODUÇÃO EM PASTAGENS, 18., Piracicaba, 2001. Anais. Piracicaba: FEALQ, 2001. p. 1- 60. 
COSTA, E.C.; RESTLE, J.; PASCOAL, L.L.; VAZ, F.N.; ALVES FILHO, D.C.; ARBOITTE, M.Z. Desempenho de novilhos Red Angus superprecoces, confinados e abatidos com diferentes pesos. Revista Brasileira de Zootecnia, v. 31, n. 1, p.129-138, 2002.

CRESPO, J.P., ANDRADE, R.L.S. Programa de qualidade da carne bovina: o desafio de satisfazer e fidelizar o consumidor. In: WORKSHOP DE QUALIDADE DA CARNE E MELHORAMENTO GENÉTICO DE BOVINOS DE CORTE, São Carlos, 1998. Anais. São Carlos: EMBRAPA Pecuária Sudeste, 1998. p. 31-41.

DE ZEN, S. Cadeia produtiva da carne bovina e o cálculo do indicador de preços do boi gordo. In: WORKSHOP EM QUALIDADE DA CARNE E MELHORAMENTO GENÉTICO DE BOVINOS DE CORTE, São Carlos, 1998. Anais. São Carlos: EMBRAPA Pecuária Sudeste, 1998. p. 45-67.

DE ZEN, S. Aspectos da produção de carne e as tendências do mercado nacional. In: SIMPÓSIO DE PRODUÇÃO DE GADO DE CORTE, 1., Viçosa, 1999. Anais. Viçosa: UFV, 1999. p. 245-264.

DELGADO, C. A pecuária até o ano de 2020: a próxima revolução alimentar (compact disc). In: CONGRESSO MUNDIAL DA CARNE, 13., Belo Horizonte, 2000. Anais. Belo Horizonte, 2000a.

DELGADO, E.F. Resfriamento e qualidade de carcaça (compact disc). In: SIMPÓSIO PECUÁRIA 2000 - PERSPECTIVAS PARA O III MILÊNIO, Pirassununga, 2000. Anais. Pirassununga: USP, FZEA, 2000b.

EGAN, A.F.; FERGUSON, D.M.; THOMPSON, J.M. Consumer sensory requirements for beef and their implications for the Australian beef industry. Australian Journal of Experimental Agriculture, v. 41, p. 855-859, 2001.

ESTADOS UNIDOS. Department of Agriculture. Putting the U.S. Cattle Industry First. http://www.fas.usda.gov/dlp/archivereports.html (15 dez. 2002).

EUCLIDES. V.P.B.; EUCLIDES FILHO, K. Produção de carne em pastagens. In: SIMPÓSIO SOBRE MANEJO DA PASTAGEM: PLANEJAMENTO DOS SISTEMAS DE PRODUÇÃO EM PASTAGENS, 18., Piracicaba, 2001. Anais. Piracicaba, FEALQ, 2001. p. 321-350.

EUCLIDES, V.P.B.; MACEDO, M.C.M.; VIEIRA, A.; OLIVEIRA, M.P. Valores nutritivos de cinco gramíneas sob pastejo. In: REUNIÃO ANUAL DA SOCIEDADE BRASILEIRA DE ZOOTECNIA, 32., Fortaleza, 1996. Anais. Fortaleza: SBZ, 1996. p. 90-92. 
EUCLIDES FILHO, K. Produção de bovinos de corte e o trinômio genótipo ambiente-mercado. Campo Grande: Embrapa Gado de Corte, 2000. 61 p.

EUCLIDES FILHO, K. O enfoque da cadeia produtiva como estratégia para a produção sustentável de carne bovina (compact disc). In: REUNIÃO ANUAL DA SOCIEDADE BRASILEIRA DE ZOOTECNIA, 41., Campo Grande, 2004. Anais. Campo Grande: SBZ, 2004.

EUCLIDES FILHO, K.; EUCLIDES, V.P.B.; FIGUEIREDO, G.R. Efeito da suplementação com concentrado sobre a idade de abate e características de carcaça do animal Nelore. Revista Brasileira de Zootecnia, v. 26, n. 6, p. 1096-1102, 1997a.

EUCLIDES FILHO, K.; EUCLIDES, V.P.B.; FIGUEIREDO, G.R. de; CARVALHO, J. Avaliação de animais Nelore e seus mestiços com Charolês, Fleckvieh e Chianina, em três dietas. 2. Características de carcaça. Revista Brasileira de Zootecnia. v. 26, n.1, p. 73-79, 1997b.

FARIA, V.P. de. Produção de bovinos nos trópicos. In: PEIXOTO, A.M.; MOURA, J.C. de; FARIA, V.P. de (Ed.). Bovinocultura de corte: fundamentos da exploração racional. Piracicaba: FEALQ, 1999. p. 23-42.

FAVARET FILHO, P.; DE PAULA, S.R. Cadeia da carne bovina: o novo ambiente competitivo. In: SIMPÓSIO O NELORE DO SÉCULO XXI, 4., Uberaba, 1997. Anais. Uberaba: ABCZ \& Nelore, 1997. p. 125-141.

FELICIO, P.E. de. Dois aspectos de competitividade da carne de Bos indicus, um positivo, outro negativo. In: CONGRESSO BRASILEIRO DE RAÇAS ZEBUÍNAS, Uberaba, 1994. Anais. Uberaba: ABCZ, 1994. p. 63-71.

FIELD, R.A. Effect of castration on meat quality and quantity. Journal of Animal Science, v. 32, n. 5, p. 849-856, 1971.

FNP CONSULTORIA \& COMÉRCIO. ANUALPEC 2002: anuário estatístico da pecuária de corte. São Paulo, 2002. 400 p.

FNP CONSULTORIA \& COMÉRCIO. ANUALPEC 2003: anuário estatístico da pecuária de corte. São Paulo, 2003. 400 p.

FOOD AND AGRICULTURAL POLICY RESEARCH INSTITUTE. U.S. and world agricultural outlook: staff report. Ames: Iowa State University; Columbia: University of Missouri, 2004. 451 p. 
FRIES, L.A. Cruzamentos em gado de corte. In: SIMPÓSIO SOBRE PECUÁRIA DE CORTE: PRODUÇÃO DE NOVILHO DE CORTE, 4., Piracicaba, 1996. Anais. Piracicaba: FEALQ, 1996. p.109-128.

FRIZZO FILHO, A.J. A realidade e o potencial da indústria do couro bovino no Brasil (compact disc). In: ENCONTRO DO NOVILHO PRECOCE, 8., Araçatuba, 2003. Anais. Araçatuba, 2003.

GALVÃO, J.G.; FONTES, C.A.A.; PIRES, C.C.; CARNEIRO, L.H.D.M.; QUEIROZ, A.C.; PAULINO, M.F. Características e composição física da carcaça de bovinos não-castrados, abatidos em três estágios de maturidade (Estudo II) de três grupos raciais. Revista Sociedade Brasileira de Zootecnia, v. 20, n. 5, p. 502-512, 1991.

GOLL, D.E.; HOEKSTRA, W.G.; BRAY, R.W. Age-associated changes in bovine muscle connective tissue. I. Rate of hydrolysis by collagenase. Journal of Food Science, v .29, p. 608-614, 1964.

HADDAD, C.M. A carne bovina da fonte de produção ao consumidor: problemas e propostas de soluções. In: PEIXOTO, A.M.; MOURA, J.C. de; FARIA, V.P. de (Ed.). Bovinocultura de corte: fundamentos da exploração racional. Piracicaba: FEALQ, 1999. p. 513-532.

HEDRICK, H.B.; MILLER, J.C.; THOMPSON, G.B.; FREITAG, R.R. Factors affecting Longissimus dorsi area and thickness of beef and relation between these measurements and retail yield. Journal of Animal Science, v. 24, p. 333-337, 1965.

HINCH, G.N.; LYNCH, J.J.; THWAITES, C.J. Patterns and frequency of social interactions in young grazing bulls and steers. Applied Animal Ethology, v. 9, p.15-30, 1982.

INSTITUTO BRASILEIRO DE GEOGRAFIA E ESTATÍSTICA. http://www.ibge.gov.br. (22 jun. 2005).

INSTITUTO EUVALDO LODI. Estudo sobre a eficiência econômica e competitividade da cadeia agroindustrial da pecuária de corte no Brasil. Brasília: Instituto Euvaldo Lodi; Confederação Nacional da Agricultura; SEBRAE Nacional, 2000. 398 p.

JOSAKHIAN, L.A. Associação Brasileira dos Criadores de Zebu uma empresa de genética tropical. In: SIMPÓSIO DE PRODUÇÃO DE GADO DE CORTE, 1., Viçosa, 1999. Anais. Viçosa: UFV, 1999. p. 21-28. 
JUNQUEIRA, J.O.; ALLEONI, G. O ponto de vista das áreas de ensino e pesquisa. In: WORKSHOP EM QUALIDADE DA CARNE E MELHORAMENTO GENÉTICO DE BOVINOS DE CORTE, São Carlos, 1998. Anais. São Carlos: EMBRAPA Pecuária Sudeste, 1998. p. 69-75.

KICHEL, A.N.; MIRANDA, C.H.B.; ZIMMER, A.H. Degradação de pastagens e produção de bovinos de corte com a integração agricultura x pecuária. In: SIMPÓSIO DE PRODUÇÃO DE GADO DE CORTE, 1., Viçosa, 1999. Anais. Viçosa: UFV, 1999. p. 201-234.

KOCH, R.M.; DIKEMAN, M.E.; CUNDIFF, L.V. Characterization of biological types of cattle (Cycle III). V. Carcass wholesale cut composition. Journal of Animal Science, v. 54, n. 6, p. 1160-1168, 1982.

KOOHMARAIE, M. Biochemical factors regulating the toughening and tenderization processes of meat. Meat Science, v. 43, p. S193-S201, 1996.

KOOHMARIE, M.; VEISETH, E.; KENT, M.P.; SHACKELFORD, S.D.; WHEELER, T.L. Understanding and managing variation in meat tenderness (compact disc). In: REUNIÃO ANUAL DA SOCIEDADE BRASILEIRA DE ZOOTECNIA, 40., Santa Maria, 2003. Anais. Santa Maria: SBZ, 2003.

KUYPERS, R. Meat tenderness: an examination of breed differences, post mortem processing, and their interactions. s.l.: Food Science Australia, 2000. 114p. (Final Report of Project STR023 Meat and Livestock Australia).

MADALENA, F.E. Produção de carne com mestiços de raças leiteiras. In: SIMPÓSIO DE PRODUÇÃO DE GADO DE CORTE, 2., Viçosa, 2001. Anais. Viçosa: UFV, 2001. p.117-136.

MARASCHIN, G.E. Caracterização de sistemas de produção em pastagens. Planejamento de sistemas de produção em pastagens. In: SIMPÓSIO SOBRE MANEJO DA PASTAGEM: PLANEJAMENTO DE SISTEMAS DE PRODUÇÃO EM PASTAGENS, 18., Piracicaba, 2001. Piracicaba: FEALQ, 2001. p. 1- 60.

MARCATTI NETO, A.M.; RUAS, J.R.M.; AMARAL, R. Vaca de leite bezerro de corte. Carne bovina: eficiência produtiva e mercado. Informe Agropecuário, v. 21, n. 205, p.64-69, jul./ago. 2000.

MAY, S.G.; DOLEZAL, H.G.; GILL, D.R.; RAY, F.K.; BUHANAN, D.S. Effects of days feed, carcass grade traits, and subcutaneous fat removal on postmortem muscle characteristics. Journal of Animal Science, v. 70, p. 444-453, 1992. 
MICHELS, I.L.; SPROESSER, R.; MENDONÇA, C. Estudo da cadeia produtiva da carne de Mato Grosso do Sul: proposta de uma política pública: relatório de pesquisa. Campo Grande: UFMS, DEA, GEA, 2000.

MICROSOFT. SQL SERVER versão 5.0, 2002.

MORAES, S.S. Importância da suplementação mineral para bovinos de corte. In: CURSO SOBRE SUPLEMENTAÇÃO MINERAL EM BOVINOS, 4., Campo Grande, 2001. Campo Grande: EMBRAPA Gado de Corte, 2001. p. 1-10.

MÜLLER, L.; PRIMO, A.T. Influência do regime alimentar no crescimento e terminação de bovinos e na qualidade da carcaça. Pesquisa Agropecuária Brasileira, v. 21, n. 4, p. 445-452, 1986.

NEHMI FILHO, V.A. Perspectiva para a pecuária. http://www.fnp.com.br/institucional/index.html (05 jul. 2005).

NEVES, M.F.; ZYLBERSZTAJN, D.; MACHADO FILHO, C.P.; BOMBIG, R.T.; RIBEIRO, A.R.B.M.; CALEMAN, S.M.Q. A cadeia produtiva de carne bovina e o Mato Grosso do Sul. Ribeirão Preto: USP, FEA, 2001. 53 p.

NOUR, A.Y.M.; THONNEY, M.L.; STOUFFER, J.R.; WHITE Jr., W.R.C. Changes in primal cut yield with increasing weight of large small cattle. Journal of Animal Science, v. 57, p. 1166-1172, 1983.

OLTJEN, J.W.; GARRETT, W.N. Effects of body weight, frame size and rate of gain on the composition of gain of beef steers. Journal of Animal Science, v. 66, n. 7 , p. $1732-1738,1988$.

OWENS, F.N.; DUBESKI, P.; HANSON, C.F. Factors that alter the growth and development of ruminants. Journal of Animal Science, v. 71, p. 3138-3150, 1993.

OWENS, F.N.; GILL, D.R.; SECRIST, D.S.; COLEMAN, S.W. Review of some aspects of growth and development of feedlot cattle. Journal of Animal Science, v. 73, p. 3152-3172, 1995.

PARDI, M.C.; SANTOS, I.F. dos; SOUZA, E.R. de; PARDI, H.S. Ciência, higiene e tecnologia da carne. 2.ed. Goiânia: UFG, 2001. v.1, 623 p.

PEARSON, A.M. Desirability of beef - its characteristics and their measurement. Journal of Animal Science, v. 25, p. 843-854, 1966. 
PEDROSO, E.K. Indicadores de qualidade de carcaça (compact disc). In: SIMPÓSIO PECUÁRIA 2000 - PERSPECTIVAS PARA O III MILÊNIO, Pirassununga, 2000. Anais. Pirassununga: USP, FZEA, 2000a.

PEREIRA, R.M.A.; SYRES, D.J.; GOMIDE, J.A.; VIDIGAL, G.T. Competição de 10 gramíneas para capineiras, no cerrado, em 1965. Revista Ceres, v. 13, p. 141-153, 1966.

PEROBELLI, Z.V.; RESTLE, J.; MÜLLER, L. Estudo das carcaças de vacas de descarte das raças Charolês e Nelore. Pesquisa Agropecuária Brasileira, v. 30, n. 3, p. 409-412, 1995.

PERON, A.J.; FONTES, C.A.A.; LANA, R.P.; QUEIROZ, A.C.; PAULINO, M.F.; SILVA, D.J. Medidas quantitativas e proporções de músculos, tecido adiposo e ossos da carcaça de novilhos de cinco grupos genéticos, submetidos à alimentação restrita e ad libitum. Revista Sociedade Brasileira de Zootecnia, v. 22, n. 5, p. 813-819, 1993.

PERON, A.J.; FONTES, C.A.A.; LANA, R.P.; SILVA, D.J.; QUEIROZ, A.C.; PAULINO, M.F. Tamanho de órgãos internos e distribuição da gordura corporal em novilhos de cinco grupos genéticos, submetidos à alimentação restrita e ad libitum. Revista Sociedade Brasileira de Zootecnia, v. 24, n. 1, p. 126-1137, 1995.

PEROTTO, D.; MOLETTA, J.L.; CUBAS, A.C. Características da carcaça de bovinos Canchin e Aberdeen angus e de seus cruzamentos recíprocos terminados em confinamento. Ciência Rural, v. 29, n. 2, p. 331-338, 1999.

PICCHI, V. Divisão da carcaça bovina em quartos, desossa e conservação pelo frio: curso teórico e prático cortes cárneos bovinos (compact disc). Campinas: ITAL, 2000.

PINEDA, N.R. Fatores que afetam a imagem e o marketing da carne no Brasil. In: SIMPÓSIO O NELORE DO SÉCULO XXI, 4., Uberaba, 1997. Anais. Uberaba: ABCZ \& Nelore, 1997. p. 19-35.

PINEDA, N.R. O uso da informação no mercado da carne, o papel do SIC (compact disc). In: SIMPÓSIO DA ASSOCIAÇÃO DE CRIADORES DE NELORE DO BRASIL, Ribeirão Preto, 2004. Anais. Ribeirão Preto: ACNB, 2004.

PURCELL, W.D. Communicating value to cattle producers: Issues, opportunities, and looking ahead. Journal of Animal Science, v. 80, Suppl.1, p. E87-E93, 2001. 
RESENDE, F.D. Índices de produtividade na pecuária de corte (compact disc). In: WORKSHOP PRODUÇÃO DE BOVINOS EM PASTAGENS, Jaboticabal, 2003. Anais. Jaboticabal: UNESP, FCAV, 2003.

RESTLE, J.; VAZ, F.N. Eficiência e qualidade na produção de carne bovina (compact disc). In: REUNIÃO ANUAL DA SOCIEDADE BRASILEIRA DE ZOOTECNIA, 40., Santa Maria, 2003. Anais. Santa Maria: SBZ, 2003.

RESTLE, J.; GRASSI, C.; FEIJÓ, G.L.D. Características das carcaças e da carne de bovinos inteiros ou submetidos a duas formas de castração, em condições de pastagem. Revista Sociedade Brasileira de Zootecnia, v. 25, n. 2, p. 334-343, 1996.

RESTLE, J.; KEPLIN, L.A.S.; VAZ, F.N.; Características quantitativas da carcaça de novilhos Charolês, abatidos com diferentes pesos. Pesquisa Agropecuária Brasileira, v. 32, n. 8, p. 851-856, 1997.

RESTLE, J.; SILVA, L.C.R.; DALLA PORTA, M.A. Desempenho de vacas de corte submetidas a diferentes manejos durante a terminação em confinamento (compact disc). In: REUNIÃO ANUAL DA SOCIEDADE BRASILEIRA DE ZOOTECNIA, 27., Campinas, 1990. Anais. Campinas: SBZ, 1990.

RESTLE, J.; VAZ, F.N.; ROSO, C.; OLIVEIRA, A.N.; CERDÓTES, L.; MENEZES, L.F.G. Desempenho e características da carcaça de vacas de diferentes grupos genéticos em pastagem cultivada com suplementação energética. Revista Brasileira de Zootecnia, v. 29, n. 5, p. 1813-1823, 2001.

RESTLE, J.; VAZ, F.N.; FEIJÓ, G.L.D.; IVAN, L.B.; ALVES FILHO, D.C. BERNARDES, A.C.; FATURI, C.; PACHECO, P.S. Características de carcaça de bovinos de corte inteiros ou castrados de diferentes composições raciais Charolês x Nelore. Revista Brasileira de Zootecnia, v. 29, n. 5, p. 1371-1379, 2000.

RESURECCION, A.V.A. Sensory aspects of consumer choice for meat and meat products. Meat Science, v. 66, p. 11-20, 2003.

RHEE, M.S.; WHEELER, T.L.; SHACKELFORD, S.D.; KOOHMARAIE, M. Variation in palatability and biochemical traits within and among eleven beef muscles. Journal of Animal Science, v. 82, p. 534-550, 2004.

ROBIN, B.; HART, A.M. Why is marbling important? An exporter's perspective (compact disc). In: MARBLING SYMPOSIUM 2001, s.I., 2001. s.I.: BEEF CRC, 2001. 
ROLAND, M.; SCHROEDER, T. Marginal value of quality attributes for natural and organic beef. Journal of Agricultural \& Applied Economics, v. 34, p. 39-49, 2002.

ROSA, I.V. Suplementação alimentar de bovinos na estação chuvosa e no período seco. In: CURSO SOBRE SUPLEMENTAÇÃO MINERAL EM BOVINOS, 4., Campo Grande, 2001. Campo Grande: EMBRAPA Gado de Corte, 2001. p. 20-26.

SAINZ, R.; VERNAZZA PAGANINI, R.F. Effects of different grazing and feeding periods on performance and carcass traits of beef steers. Journal of Animal Science, v. 82, p. 292-297, 2004.

SALEK, M.L.A. Características de carcaça, rendimentos de desossa e qualidade da carne de touros jovens da raça Nelore. Campinas, 1998. 72 p. Dissertação (M.S.) - Faculdade de Engenharia de Alimentos, Universidade Estadual de Campinas.

SANTIAGO, A.A. Pecuária de corte no Brasil Central. Nova Odessa: Instituto de Zootecnia, 1970. 639 p.

SANTOS, A.M.M.M.; CORREA, A.R.; ALEXIM, F.M.B.; PEIXOTO, G.B.T. Panorama do setor de couro no Brasil. BNDES Setorial, n. 16, p. 57-84, 2002.

SAS INSTITUTE. SAS/STAT ${ }^{\mathrm{TM}}$ guide for personal computers. 8.02.ed. Cary, 2001. 1028 p.

SEIDEMAN, S.C.; ROSS, H.R.; OLTJEN, R.R.; SCHANBACHER, B.D. Utilization of the intact male for red meat production: a review. Journal of Animal Science, v. 55, n. 4, p. 826-840, 1982.

SHORT, R.E; GRINGS, E.E; MacNEIL, M.D.; HEITSCHMIDT, R.K.; WILLIAMS, C.B.; BENETT, G.L. Effects of sire growth potential, growing-finishing, and time on feed performance, composition, and efficiency of steers. Journal of Animal Science, v. 77, p. 2406-2417, 1999.

SHORTHOSE, W.R.; HARRIS, P.V. Effect of animal age on the tenderness of selected beef muscles. Journal of Food Science, v. 55, p. 1-8, 1990.

SOUZA, M.L. de; MONTENEGRO, M.A.A.C. Subprodutos comestíveis da indústria da carne. Higiene Alimentar, v. 14, n. 72, p. 27-34, 2000. 
TATUM, J.D.; SMITH, G.C.; BELK, K.E. New approaches for improving tenderness, quality, and consistency of beef. In: PROCEEDINGS OF THE AMERICAN SOCIETY OF ANIMAL SCIENCE, 1999.

http:www.asas.org/jas/symposia/proceedings/0925.pdf (15 ago. 2002).

TATUM, J.D.; SMITH, G.C., CARPENTER, Z.L. Interrelationship between marbling, subcutaneous fat thickness and cooked beef palatability. Journal of Animal Science, v. 54, n. 4, p. 777-784, 1982.

TAYLOR, R.G. Meat tenderness: theory and practice. Brazilian Journal of Food Technology, v. 6, p. 56-66, 2003. Special Issue.

TOKARNIA, C.H.; DÖBEREINER, J.; MORAES, S.S.; PEIXOTO, P.V. Deficiências e desequilíbrios minerais em bovinos e ovinos - revisão nos estudos realizados no Brasil de 1987 a 1998. Pesquisa Veterinária Brasileira. v. 9, n. 2, p. 47-62, 1999.

TUNDISI, A.G.A.; LIMA, F.P.; KALIL, E.B.; VILLARES, J.B.; CORREA, A.; VIDAL, M.E.P. Novas interpretações sobre as eficiências das provas de ganho de peso e a viabilidade da produção econômica de novilhos zebus próximos dos 24 meses de idade. Boletim Indústria Animal, v. 23, p. 6781, 1965/1966.

VIEIRA, J.M.; KICHEL, A.N. Estabelecimento e recuperação de pastagens de Panicum maximum. In: SIMPÓSIO SOBRE MANEJO DA PASTAGEM, 12., Piracicaba, 1995. Anais. Piracicaba: FEALQ, 1995. p.147-196.

VILELA, L.; MARTHA JÚNIOR, G.B.; BARIONI, L.G.; BARCELLOS, A.O. Adubação na recuperação e na intensificação da produção animal em pastagens. In: SIMPÓSIO SOBRE MANEJO DA PASTAGEM: FERTILIDADE DO SOLO PARA PASTAGENS PRODUTIVAS, 21., Piracicaba, 2004. Anais. Piracicaba: FEALQ, 2004. p. 155-216.

VILLARES, J.B. Exploração do ganho compensatório para produção de bovinos no trópico. In: PEIXOTO, A.M.; MOURA, J.C. de.; FARIA, V.P. de (Ed.). Nutrição de bovinos: conceitos básicos e aplicados. 5.ed. Piracicaba: FEALQ, 1995. p.251-290.

WHEELER, T.L.; CUNDIFF, L.V.; KOCH, R.M.; CROUSE, J.D. Characterization of biological types of cattle (cycle IV): carcass traits and longissimus palatability. Journal of Animal Science, v. 74, p. 1023-1035, 1996. 
WHIPPLE, G.; KOOHMARAIE, M.; DIKEMAN, E.; CROUSE, J.D.; HUNT, M.C.; KLEMM, R.D. Evaluation of attributes that affect longissimus muscle tenderness in Bos Taurus and Bos indicus cattle. Journal of Animal Science, v. 68, p. 2716-2728, 1990.

ZIMMER, A.H.; EUCLIDES FILHO, K. As pastagens e a pecuária de corte brasileira. In: SIMPÓSIO INTERNACIONAL SOBRE PRODUÇÃO ANIMAL EM PASTEJO, Viçosa, 1997. Anais. Viçosa: UFV, 1997. p. 349-379. 